University of Louisville

ThinkIR: The University of Louisville's Institutional Repository

Electronic Theses and Dissertations

1940

\title{
A study of oleoresinous film structure.
}

Frank Rush McQuilkin

University of Louisville

Follow this and additional works at: https://ir.library.louisville.edu/etd

Part of the Chemical Engineering Commons

\section{Recommended Citation}

McQuilkin, Frank Rush, "A study of oleoresinous film structure." (1940). Electronic Theses and Dissertations. Paper 1844.

https://doi.org/10.18297/etd/1844

This Master's Thesis is brought to you for free and open access by ThinkIR: The University of Louisville's Institutional Repository. It has been accepted for inclusion in Electronic Theses and Dissertations by an authorized administrator of ThinkIR: The University of Louisville's Institutional Repository. This title appears here courtesy of the author, who has retained all other copyrights. For more information, please contact thinkir@louisville.edu. 
UNIVERSITY OF LOUISVILLE

A STUDY OF OLEORES INOUS FILM STRUCTURE

\title{
A Theris
}

\author{
Submitted to the Faculty \\ of the Graduate School \\ of the University of Louisville \\ in Partial Fulfillment \\ of the Requirements \\ for the Degree of
}

MASTER OF CHEMICAL ENOINEERING

Department of Chemical Engineering

By

Frank Rush McQuilkin

1940 


\title{
A STUDY OF OLEORESINOUS FILY STRUCTURE
}

\author{
Frank Rugh McQuilkin
}

Approved by Examining Oomittoes

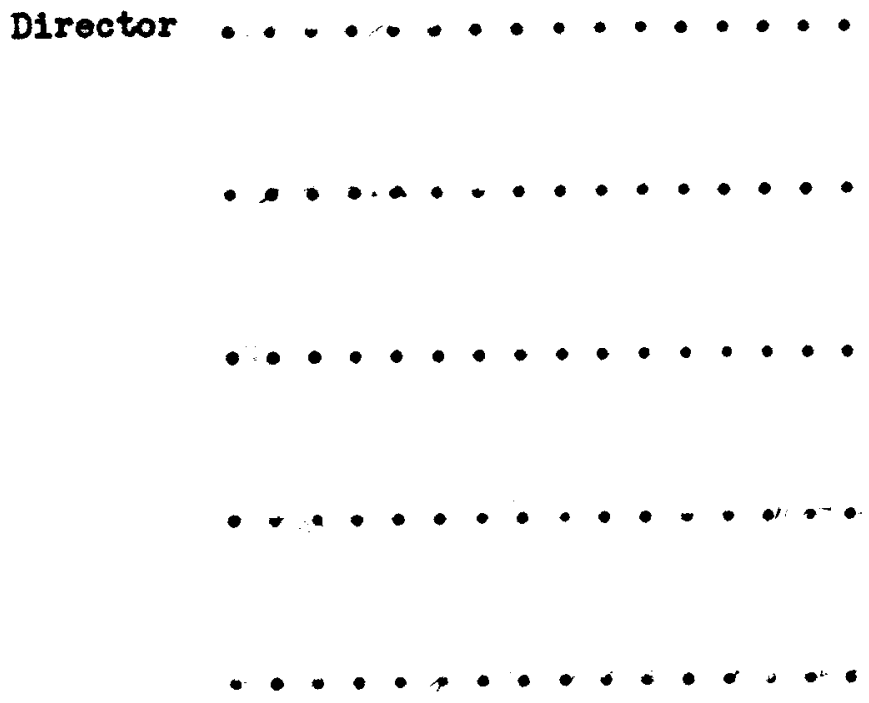

July 25, 1940 
TABLE OF OONTENTS

Page

List of Tables ........................ il

Liat of Figures ....................... . I11

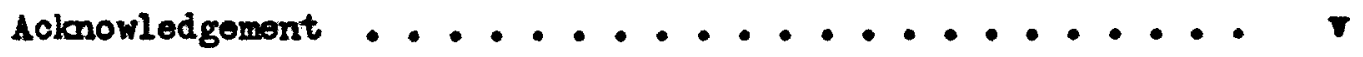

Abstract ........................... $\mathbf{1}$

Introduction ........................ 1

Historical ........................ 4

Theoretical ....................... 8

Raw Materials .................. 16

Experimental Apparatus ................. . 22

Exporimontal Procedure .................. 33

Data and Results................. 38

Discussion of Results ................. 57

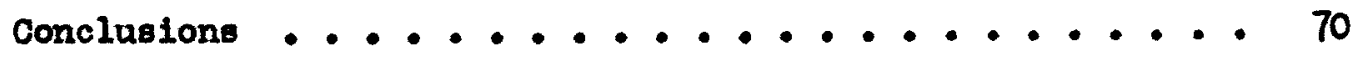

Litorature 0itod . . . . . . . . . . . . . 72

Append1x ......................... 74

Acknowledgementsm. .................... 75

vita......................... 76 
I Raw Materials ............... 19

II Formalations ................... 20

III Distensibility and Percent Unextractible of Linseed Varnishes ....................... 40

IV Distensibility and Percent Unextractible of Tung Varmishes ................. 41

v Distensibility and Percent Unextractible of Lineed

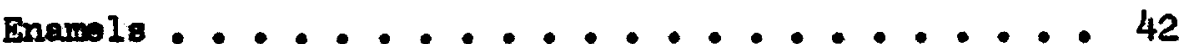

VI Distensibility and Percent Unextractible of Tung

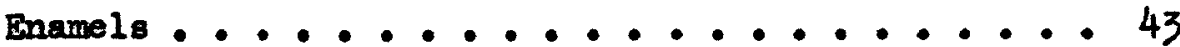

VII Extraction of Congo Resin ............ 44 VIII Percent Unextractible of Films at Pailure...... 56 
LIST OF PIQURES

Figure

Pago

1 Casting Pilm on tin panel with doctor blade..... 24

2 Accelerated weathering unit ............ 26

3 outdoor exposure fence .............. 27

4 View showing micrometer, doctor blade, oteel template and otripped film ................. 29

5 Tenoile tester used in making the distensibility tests. 30

6 Extraction unito used in extracting the films ..... 31

7 Percent Unextractible ve Age and Elongation for 33 gal. Linseed Varnish and Enamel :........... 45

8 Percent Unextractible vo Age and Elongation for $25 \mathrm{gal}$. Lineeed Varnish and Enamel .......... 46

9 Percent Unextractible vs Age and Elongation for $16 \mathrm{gal}$. Linseod Varnish and Enamel ............. 47

10 Percent Unextractible ve Age for $8 \mathrm{gal}$. Lineeed Varnish and Enamel ............................. 48

11 Percent Unextractible vo Age and Elongation for Straight Linseed 011 Films .................. 49

12 Percent Unextractible ve Age and Elongation for 33 gal. Tung Varnieh and Enamel .............. 50 
LIST OF FIGURES (continued)

Pigure

Page

13 Percent Unextractible vo Age and Elongation for $25 \mathrm{gal}$.

Tung Varnish and Enamel ................ 51

14 Percent Unextractible ve Age and Elongation for 16 gel.

Tung Varnish and Enamel .............. 52

15 Percent Unextractible ve Age for $8 \mathrm{gal}$. Tung Varnish

and Enamel ................... 53

16 Percent Unextractible vs Age and Elongation for Straight

Tung oil Films ................ 54

17 Percent Unextractible ve Age for Congo Reain Filn . . 55

18 Composite Curres for $33 \mathrm{gal}$. Linseod Varnish and Hamol 62

19 Composite Curves for $25 \mathrm{gal}$. Lineeed Varnish and Bnawol 63

20 Composite Curres for $16 \mathrm{gal}$. Lineed Varnish and 64

21 Composite Curves for 8 gal. Linseed Varnish and Enamel 65

22 Composite Curves for $33 \mathrm{gal}$. Tung Varnish and Enamel - 66

23 Composite Curves for $25 \mathrm{gal}$. Pung Varnish and Enamol - 67

24 Composite Curres for $16 \mathrm{gal}$. Tung Varnish and Enamel - 68

25 Composite Gurves for $8 \mathrm{gal}$. Tung Varnish and Enamel . 69 
ACKNOWLEDGEMENT

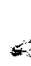

The Author whes to acknowledge the A

kind assistance and helprul guidance

of Doctor R. C. Emat, who 垈 directed this research. 
ABSTRAOT

This investigation is the firot in a series whose purpose is to establish a basis for formulating oleoresinous coatings. $A$ study of the polymerization and distensibility effects accompanying aging was correlated with accelerated exposure durabllity, showing that a film loses its elastic properties whon definite oxposure failure has set in. The three-dimensional intermolecular theory of oll polymerization is considered in portalating the cause of the film fallure.

The degree of polymerization whon failure sets in, as determined by solvent extraction, varies within a range due to the differences in olls and the ratios in which they are used with resin.

Although enamels are observed to polymerize more slowly than varnishes, films of the same materiale and oil lengthe representing each type of coating fail at the same degree of polymerizam tion. Inert pigment is shown to incorporate itself as 'polymer' when considered in this manner. The enamel failure generally occurs earlier because of the high initial insoluble content impartod by the pigment.

Composite curres are developed to show that rate of polymerization curves for varnishes and onamels containting an in- 


\section{ABSTRACT (continued)}

ert pigment can be predetermined by similar curves for the individual materials used. Such curves are incapable of predicting the expected durability of the coatings. 
INTRODUCTION 
This investigation is the first in a veries whose purpose is to study oleoresinous film structures so as to establish a sound basis for formulating oleoresinous coatings. Such a basis, if dereloped from a practical point of vion, would be of ralue to the varnish induetry in that the expected durability and properties of a coating could be prodicted by formula analysis. The present investigation is a study of the problem from the basic film structure angle. Assuming that film failure is due to some ultimate combination prosent when failuro occurs and designating this combination as the polymer-to-oil ratio, it is proposed to study the change in this ratio in the film through its lifo until failure occurs.

The determination of polymer-to-oil ratio has been based upon the assumption made by other investigatoras That the portion of the film insoluble in acetone can be considered as an index of the 'polymer' content. The term 'polymer' used here refers to those highly polymerized molecules in the film that have so linked themselves by intermolecular forces that they constitute a continuous network of ring enclosed molecules resembling lattice work. This portion of the fllm is considered insoluble in acetone and filterable. Thus pigments are included in this portion. The oil portion consists of polymorized and unpolymerized molecules which have not linked themeelves into the network of 'polymers'. They are considered soluble and unfilterable in this 
work. The Sohxlet mothod of solvent extraction was employed for the removal of the oil portion. Since this portion of the film has elastic-giving propertios wo may consider it as the plasticizer portion which will be present in a minimum allowable amount when film failure occurs. 
HISTORIOAL 
Blom (1) has done considerable pioneer work in the field of protective coating film etructures. In 1929 he made photomicrographs of the cross section of fllms showing a stratification of the pigment and other constituente. From this otudy he suggested that enormous intermolecular forces must be present in films. Elm (9) investigated the changer taking place in films of trilinolenic glyceride during exposure to room conditions. This investigation was undertaken with the hope that a stady of a simplo unsaturatod glyceride might yield information which would prove helpiul in explaining the formation and deterioration of the more complex arying oil systems and the effect exerced upon them by pigments. He concluded that oompounds less complicatea than trilinolento glyceride required study if the basic reactions involved in drying ofl reactione was to be learned.

Long $(13,14)$ likewise experimented witn pure trilinoleic and trilinolenic glycerides in connection with his colloidal association stuaies. He showed that a dried I'ilm may be divided into a soluble and insoluble phase by means of solvont extraction. Acetone was proved the most satisfactory solvent.

After analyzing the soluble liquid phase and the insoluble solid phase of linseed ofl tilms, Rose and Bolley (16) spoke of the three components constituting the Iilms ass (a) liquid, (b) adsorbed liquid, ana (c) solia. They claim that the relative proportions in which these components are present have a 
decided affect on the physioal nature of the film. Linolenic glyceride and linseed ofl Illms have been aged and extracted with acetone and it has been found that the solid phase becomes increasingly greater and the liquid phase decreasen as age increases. The unpolymerized and unassociated liquid which has not boen adsorbed are completely extracted but probably only a part of the liquid which has been adsorbod is extracted. After continued aging the pigmented olls begin to lose traces of pigment due to changes in oil structure. The authors apeak or this as a lessening of 'binding' power of the oil.

As a contimuation of ELm's ortginal work Overholt and Elm (15) followed the suggestion that less complicated compounds be used. Methyl esters of several unsaturated fatty acids were exposed to ultraviolet light for various periods of aging after which the films were analyzed for uneaturation, conjugation, oxidation, polymerization, and the change in refractive power. The method of study employed in determining the degree of polymerization was the cryoscopic molecular weight method. This determination was checked by a viecosity measurement for determining the degree of polymerization. The authors aid not seem satisfied with their results, however, they considered the possibilities of the work taken up in the present series of investigations. 'The values of these data will be found in the ract that they roduce to a comon denorinator the changes taking place auring a standard 
exposure in drying ofl esters varying in type and degree of unaaturation. When these results are contrasted with similar data obtained with the more complex glycol and glycerol esters, it should be possible to obtain a clearer insight into the mechanise of rilm formation of drying oil $\theta^{\circ}$. 
THEORETIOAL 
Oleoresinous Iilms and their structures cannot be fully appreciated without considering the chemfotry of the drying oils and reains.

Linseed ofl consiste principally of the triglycerides of the unsaturated fatty acids: Iinoleic, $40 \%$, Inolenic, $40 \%$ and oleic, 10\%. They contain two, three, and one aouble bonds in the order named. Part or the linolenic acid is in the form of isolentc acid. Also about $5 \%$ of stearic acid glyceride is present. Tung oil consists of about $75 \%$ of the triglyceride of eleostearic acid, about $15 \%$ olelc and $5 \%$ palmitic acid glycorides. The drying oils are capable of two types or reaction, double-bond polymerization and oxygen absorption (5). Outter and Jordon (7) discussed the mechanism of the double bond polymerization. They modifted the Diels-Alder reaction ( () to get a aix-membered carbon ring serving to link togother two acid radicals. Long's atudies (14) on oxygen absorption and 1088 of rolatile products on drying concluded that drying is a 'colloidal association process'. Neglecting double bond polymerization entirely, he presents a two stage drying process. In the first stage, oxygen is absorbed rorming polar molecules. These liquid polar molocules then associate to give a solid, insoluble phase. This alsociation is eupposed to take place slowly over a period of months, whereas the oxygen absorption is apparently complete in a much shorter time. Assoclation is observable to its fullest extent as soon as the 
forces which make it possible are effective.

Bradley's (2) extensive studies of film structure are based on the theory that the tri-blyceriden are three-dimeneional. He extended the general theory of polymerization developed by Carother (6) and the related theory of alkyd resins developed by Kienle (11) and appliea thom to 'drying'. He states that the molecules of soluble resins and coating compounds have linear, 2dimensional structures, while insoluble resins and dried (Insoluble) filme have the chaina cross-linked in 3-dimensional otructures. Drying consists funamentally in the convorsion of the 2-dimeneional to the 3-dimensional typo of structure. The main requirement for drying is therefore not the ability to oxidize but the possession of a unit molecule with a 'sufficient number and type of reactive centers to permit unrestricted grouth in all directions'. In other words, 'the simplest (monomeris) unit should be capable of joining with more than 2 other units'. Only one double bond in each acid radical of a drying oil ordinarily functiona as an active center. That is, of several double bonde having 'potential functionality' only one has 'wtive functionality'. Saponiflcation of polymerized or oxialzed drying oll gives dimeric acids regardless of the extent of polymerization of the o1l. He has shown geometrically that the alcohol esterified with the drying oil acid must be at least triatomic if a branched, 3-dimensional structure is to be formed. This was confirmed experi- 
mentally by the inability of glycol linoleate to dry. Later (3) he suggestod that these concepts were ouficient to explain the phenomena for the bodying of drying o1lo, without recourse to the colloidal considerations.

Another of Bradley's $(2,3)$ investigations was an examination of the 180lated fraction from solvent-extracted stand olls and their gels. He obtained ovidence that related the several phases not only to the degree of polymerization but to the extent and nature of the intramolecular reactions as woll. This work was carried out experimentally using a gelled produce derived from the heat treatment of a mixture of $89 \%$ ofticica oil and $11 \%$ sardine 0il. The gel was extractod with solvents including acetone and the resulting soluble liquid and insoluble solid phases were analyzed for aponification number, acid ralue, lodine number, molecular weights, retractive indices, and specific gravity. On making a thorough analytical study of the data obtained he found that the gel in esterifled glyceride form contained $70 \%$ of insoluble solid phese and $30 \%$ of soluble liquid phese. Only liquid esters were obtained by saponification, hydrolysis, and resterifleation with methanol. These methyl esters were separated into volatile monomeric esters and nonvolatile dimeric esters by distillation. His observation was that the ratio of the monomers to the dimers was markedly different for the two phases of the original gel. 'Obviously the gelled insoluble phase wa more 
highly polymerized than the liquid phase'. He showed that the tri-glycoride molecules react intramolecularly and intermolecularly to form dimers, trimers, polymers and eventualiy polymer ring closures. This theory combined with his original theory of the three dimensional structures formed on polymerization of the 011 and resin molecules lead to the suggestion that an aged oleoreainou film consiste of multiples of polymerized molecules intermolecularly connected in ring enclosures which in turn are intercomected to each other forming a continuous network of ring enclosures.

In connection with the intermolecular reactivity which oocurs in the polymerization of resins (this is analagous to the same type reaction occurring with the drying oils) Kienle (12) has concluded that (a) organic compounds of high molecular weight are formed only when the inter acting molecules are polyactive, (b) the interlinking of the molecules proceeds according to the chance contact of any 2 individual reactive points and (c) the relative sizes and shapes of the reacting molecules and the position of the reacting point largely determine the physical properties of the resulting polymer. He suggested that in a system involving the interaction of polyfunctional molocules, the progress of polymer formation is such that as each intermediate produce of polymeric molecule 18 formed, the functionality of this intermediate product or polymeric molecule should be con- 
sidered as if the newly formed molecule were a monomer.

If we consider the oleoresinous film as complex lattice work of three dimensional oil and reain molecules intermolecularly connected and eerving a potential frame work, we can conceive that the dimeric and monomeric molecules which have not linked themselves in the network are still available as unpolmerized (or low polymerized) liquid partially adsorbed on the polymer surfaces and extractible with solvents. As aging of a film continues, the polymerization continues and the lattice network becomes more complicated with these interwoven fibre-like molocules; thus more insolubie matter is present and lese soluble liquid or semiliquid remains. Curres showing the relation between the percent unexuractible of the Iilm and the age should show a sharp increase in the 'polymer-content' auring the early otages of aging, and a gradual increase later on when the interwoven structure has become so complicatea that the chances for Iunctional groups to contact one anothor is lossened.

The film strength which is related to exposure auram bility of a film has been measured by diatonsibility (load-elongation) methode (18). This suggests that the intrinsic lite or durability of a $\mathrm{I}^{1} 1 \mathrm{~m}$ is measuruble and can be considered in the light of the Iilm structure theory set forth above. During its early aging periods a film possesses relativety high elastic properties which decrease on continued aging. After the Iilm 
has dried surficiently to pessess elasticity, a weak intermolecular network has built up by polymerization to a point where there is an appreciable insoluble portion in the film. On tarther aging this network has developed more strongly and the elasticity should be even greater. However, on contimued aging the intermolecular network has become so complicated by adaitional polymerization and Iinkages that the tendency for it to streten under an applied load is leseened. When a Iilm has agod to the point where its elasticity approaches zero, wo would expeet it to be a very complex network of polynere unable to withstand exuernal atresees because of its interwoven complexity. These stresees might be set up by elongation tests or they might be uet up by those energies which cause ordinary failure on exposure. At this zero point it would be expected that the 'polymer-content' of the IIIm be high and probably on the gracual rise portion of the curve mentioned above.

If this theory be true then we would expect to find the 'polymer-oontent' of all oleoreainous rilme to be within a limited range at the exuct zero point of railure. Theoretically, the only variations to this would be in the basic differences of the materiate used in the formulation and in the ratios in which they are used.

Practically, the determination of the exact age at which the lasticity or a film becomes zero is indeterminable even 
if all other condition are perfectly controllec. Howerer, by the use of curves a close approximation should be obtainable. In conducting this investigation one resin, two oils, and one pigment were aged, longated, and extracted individualiy (where possible) una together in dirferent oleoresinous ratios in an efIort to obtain data supporting or dereating the theory set forth. 
RAW MATERIALS 
The materials used in preparing the formalations are listed in Table I. The properties of these raw materials are given below.

The linseed oil was a bodied $\mathrm{z}-3$ oll having an lodine number of 120.3 . The china rood or tung ofl was A.D.M. No. 50 calorized oil having an lodine mumber of 131.2 .

Mineral epirits having a opecific gravity of 0.791 and a boiling range of $153-204^{\circ} \mathrm{O}$ was used in thinning the rarnishos ana oll formulations. Butyl acetate having a spectfic gravity or approximately 0.815 and a boiling range of $115-130^{\circ} 0$ was used as the solvent for the congo spirit varnish. The acetone used as the extracting solvent had a specific gravity of 0.792 and a bolling range of $50.1-57^{\circ} \mathrm{O}$ :

Numbers 11 and 12 bold amber Congo realn, 'run' at $610^{\circ} \mathrm{F}$ ana having an acetone insolubility of $24 \%$, was the resin ueed in preparing all formulations.

Pure Rayox grade non-chalking titantum dioxicte bulking 0.03118 pounds per gallon having an 011 abosrption of 24.2 and a secific gravity of 3.88 was uoed as the pigment in all enamels. The $\mathrm{TiO}_{8}$ was ground in $65 \%$ pastes on a laboratory mill at three passes per paste to obtain proper dispersions of the pigment in the ofls. The pigment weight ratio was 2.251 bs. of $\mathrm{TiO}_{\mathrm{a}}$ per 4 lbs. of initial colids present. All enemel formulations were checked for satiafactory dispersions by means of the 
microscope.

Liquia Nuodex lead ad manganese driers containing $24 \%$ and $6 \%$ metul, respectively, were added to the varnish and enamel formulations on a metal-to-0il weight basis of $0.60 \%$ lead and $0.06 \%$ manganese. A $60 \mathrm{gallon}$ lead and manganese drior consisting of linseed oil and rosin was added to the straight oil eamples on a rolume basis of one part drier to nineteen parts oil. This arfer was used because of afflculties in obtaining artisfactory I1lms with straight oil samples containing the Nuodex driers. The errors introduced by this difference in driers can be only slight. In addition to this change in driers it was still necessury to dry the otraight tung oil films in an atmosphere of oxygen to prevent gas-checking.

The 8 and 53 gallon length varnishes were prepared by cooking the resin with the oils at $560^{\circ} \mathrm{F}$, thinning at $450^{\circ} \mathrm{F}$ with mineral spirits and filtering at about $200^{\circ} \mathrm{F}$. The 16 and 25 gellon length rarnishes were prepared by blending the 8 and 33 gallon varniohes in the proper calculated ratios. The onele were prepared by pigmenting portions of the varnishes.

The formulations are shown in Table II. 
TABLE I

\section{RAW MATERIALS}

Drying 0ils

Reein

Solrents

Driere

Pigment

Z-3 Bodied Iinseed

Bold Amber Congo

A.D.M. No. 50 Tuns
Mineral

Spirito

Buty 1

Acotato

Acetone
Nuodex

Lead

Nuodex

Manganere

Lead and

vangenesp in

Inseed var-

nish drier
Rayox

Titanium

Dioxide 
TABLE II

FORMULATIONS

\begin{tabular}{|c|c|c|c|c|c|c|}
\hline $\begin{array}{l}\text { Formala } \\
\text { Code* }\end{array}$ & $\begin{array}{l}\text { 011 length } \\
\text { in gallons }\end{array}$ & Drying o1l & $\begin{array}{l}\text { Type of } \\
\text { Pinish }\end{array}$ & Th1nner & Drier & $\begin{array}{l}\text { Percent } \\
\text { Selids }\end{array}$ \\
\hline CHI & 33 & Llmseod & Varnish & M.S. & Nuodex $\mathrm{Pb} \& \mathrm{Min}$ & 51.1 \\
\hline $\mathrm{CL} 2$ & 25 & Ilnseed & Varndah & M.S. & Muodex Pb \& $\mathrm{Mn}$ & 48.3 \\
\hline CIB & 16 & Linseed & Varnish & M.S. & Nuodex $\mathrm{Pb}$ \&c $\mathrm{Im}$ & 51.5 \\
\hline CIA & 8 & Linseed & Varnish & M.s. & Nuedex $\mathrm{Pb} \& \mathrm{Mn}$ & 51.4 \\
\hline CL5 & $\infty$ & Iinseed & Stralght 11 & M.S. & $\begin{array}{l}\text { Pb \& Min in Iinseod } \\
\text { Varnioh drier }\end{array}$ & 75.1 \\
\hline CTI & 33 & Tung & Varnish & M.S. & Muodex $\mathrm{Pb} \& \mathrm{Mn}$ & 50.2 \\
\hline CT2 & 25 & Tung & Varnish & M.S. & Nuedex Pb \& ith & 50.0 \\
\hline CTB & 16 & Tung & Varnish & M.S. & Nuodex Pb \& Mn & 51.7 \\
\hline CT4 & 8 & Tung & Varnish & Mos. & Nuodex $\mathrm{Pb} \& \mathrm{Mn}$ & 55.2 \\
\hline CT5 & $\infty$ & Tung & Straight $\bullet 11$ & - & $\begin{array}{l}\mathrm{Pb} \& \text { in Linseed } \\
\text { Varnish drier }\end{array}$ & 96.6 \\
\hline
\end{tabular}

* C - designates ramigh series, I - linseed eil, T - tung 011, 1 - 33 gallen lemgth, 2 - 25 gallon, 3 - 16 gallon, 4 - 8 gallon, 5 - straight o1l. 
TABIE II (continued)

FORMULATIONS

\begin{tabular}{|c|c|c|c|c|c|c|}
\hline $\begin{array}{l}\text { Formula } \\
\text { Cede }\end{array}$ & $\begin{array}{l}011 \text { length } \\
\text { in gellons }\end{array}$ & Drying o11 & $\begin{array}{l}\text { Trpe of } \\
\text { finieh }\end{array}$ & Thinnor & Drier & $\begin{array}{l}\text { Percent } \\
\text { Sollds }\end{array}$ \\
\hline DLPI & 33 & Linseed & Enomol & M.S. & Nuodex $\mathrm{PB} \& \mathrm{Mn}$ & 63.0 \\
\hline DLP2 & 25 & Innseed & Inamel & M.S. & Nuedex $\mathrm{Pb} \& \mathrm{Mn}$ & 61.2 \\
\hline DLP3 & 16 & Linseed & Bnamel & M.S. & Muodex $\mathrm{Pb} \& \mathrm{Mn}$ & 63.7 \\
\hline DLP4 & 8 & Ilnseed & Enamel & M.S. & Muedex $\mathrm{Pb} \& \mathrm{Mn}$ & 68.3 \\
\hline DLPS & $\infty$ & Linseed & P1g. in 011 & M.S. & $\begin{array}{l}\mathrm{Pb} \& \text { Mn in Iinseod } \\
\text { Varnish drier }\end{array}$ & 82.6 \\
\hline DTP1 & 33 & Tung & Ename1 & $\mathbf{M} \mathbf{s}$. & Nuodex $\mathrm{Pb} \& \mathrm{in}$ & 61.5 \\
\hline DTP2 & 25 & Tuns & Enamel & M.S. & Thoodex $\mathrm{Pb} \& \mathrm{Mn}$ & 61.8 \\
\hline DIP3 & 16 & Tung & Ename 1 & M.S. & Nuedex $\mathrm{Pb}$ \&c $\mathrm{Mn}$ & 63.6 \\
\hline DPPL & 8 & Tung & Enamel & M.S. & Nuodex $\mathrm{Pb} \& \mathrm{Mn}$ & 66.3 \\
\hline DTP5 & $\infty$ & Tung & P1g. in ofl & - & $\begin{array}{l}\text { Ph \& Mn in Lingeed } \\
\text { Varnish drier }\end{array}$ & 98.7 \\
\hline cs & 0 & none & $\begin{array}{l}\text { Spirit } \\
\text { rarnish }\end{array}$ & $\begin{array}{l}\text { Butyl } \\
\text { acetate }\end{array}$ & none & 42.7 \\
\hline
\end{tabular}


EXPERIMENTAI APPARATUS 
The apparatus used in this investigation consisted of soveral etandara and sereral unique pieces of equipment, all of which are described below.

PILM CASTERS. Films were cast with a doctor blade (10) oapable of depositing uniformly thick films. The caster is simply an upright piece of steel having spacers at the ends fastoned to the blade so as to make a gap-width of 0.01 inch when set upright on a plane. This caster has an overall width of $4 \frac{1}{2}$ inches and deposits a film $3 \frac{1}{8}$ inches wide. $A 11$ films were cast with this caster by the same operator who used a pulling stroke at a unirorm rate of about 18 inches per minute. Films caat by this method dried to a unitorm thickness in the range of 0.002 to 0.003 inch depending upon the solid content of the ample. See: Figs. 1 and 4.

PANELS. All rilme were cast on 31 gage coke tin panele $5 \times 10$ inches in size having $\frac{1}{4}$ inch holes centered of Inch from the tops. To facilizate clean and uniform films on the tin surface each panel was carefully cleaned with ethyl alcohol and placed upon a leveled plate glass for the film casting. The panels were made to aahere smoothly to the glasg surface by opreading a water film between the two surfaces. This was done by placing several drops of water on the glass and firmly pressing the panel upon the two. The films were removed from the tin aurface by amalgamation with technical mercury, thus producing free tilms. 


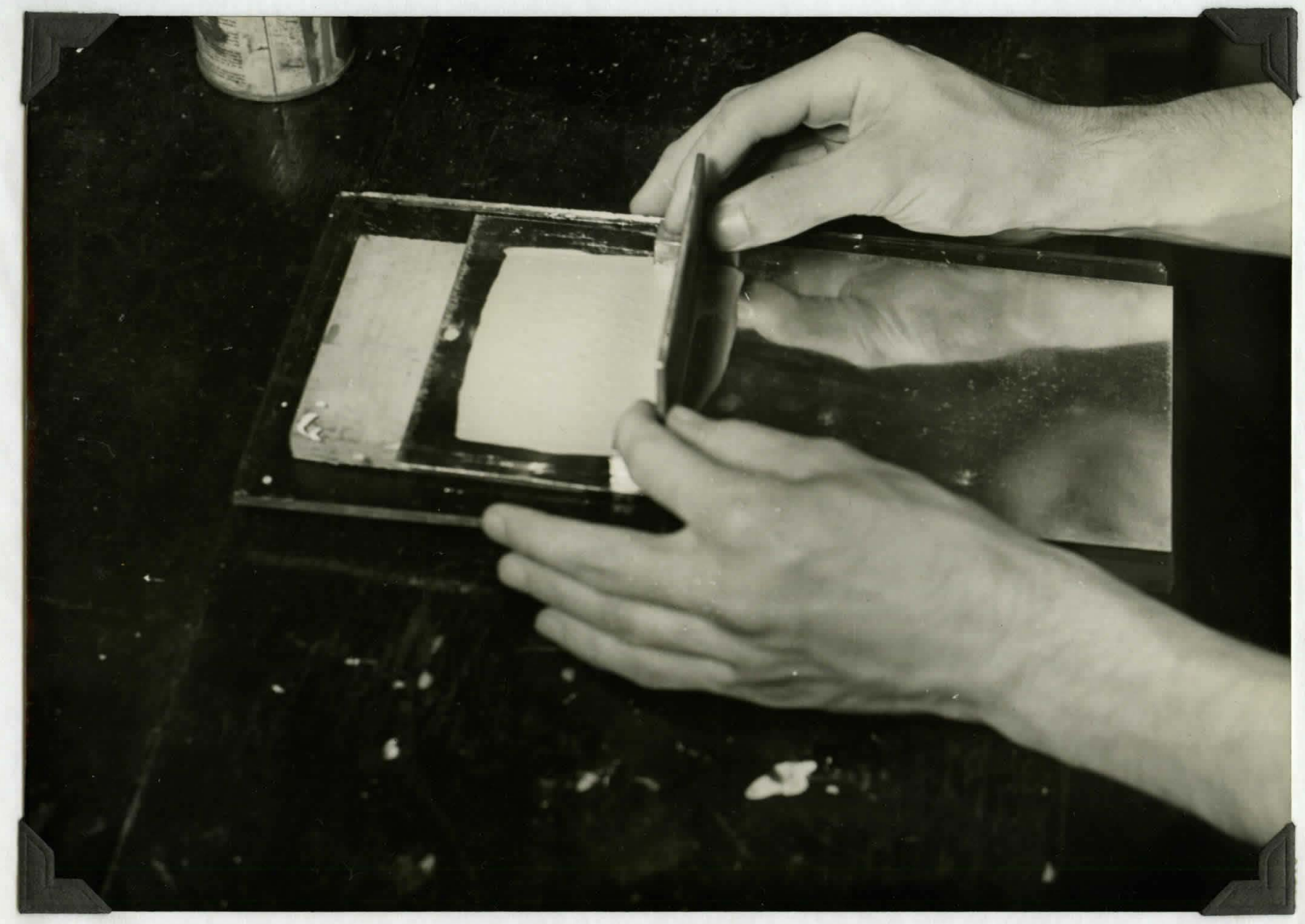

Fig. 1. Casting film on tin panel with dector blade. 
ACCELERATED WEATHERING UNIT. A National Oarbon Company Accelerated Weathering Unit operating at 60 amperes and burning Nos. 13 and 22 UCC sunshine carbons was used. This unit weathered 64 3 * 10 inch panels simultaneously. It was operated at $75^{\circ} \mathrm{C}\left(107^{\circ} \mathrm{F}\right)$ during the dry heat and light portion of the cycle and at $38.40^{\circ} \mathrm{C}$ (100.4-104.0) during the moist heat and light portions. A refrigerator maintaining a temperature of $-20^{\circ} \mathrm{C}\left(-4^{\circ} \mathrm{F}\right)$ was operatod in conjunction with the weathering unit for the cold portion of the cycle. The cycle solocted for this investigation is one devoloped by the Commonwealth Edison Company of Chicago. A callbration of this cycle and untt for outdoor weather in Loulavilie is in progreas at this writing. The continuous dally sidedule conetituting one cycle is a followe: (Unit is shown in $\mathrm{PIg}$. 3).

\begin{tabular}{|c|c|c|}
\hline & $\begin{array}{l}\text { Light and water opray } \\
\text { Light without water } \\
\text { Light and water opray } \\
\text { Water spray alone } \\
\text { Rest poriod } \\
\text { Refrigeration }\end{array}$ & $\begin{array}{l}\text { DAM- } \\
0 \text { PM- }\end{array}$ \\
\hline
\end{tabular}

OUTDOOR TEST PANEL FENCE. A test fence accomodating 150 test panels was built on the roof of the laboratory building for the purpose of calibrating the accelerated weathering unit. The fence was built so as to give a ' $45^{\circ}$ south' exposure. See Fig. 2. CONSTANT-TEMPERATURE, CONSTANT-HUMIDITY ROOM. A well weatherstripped room encased on the outside with brick and located on 


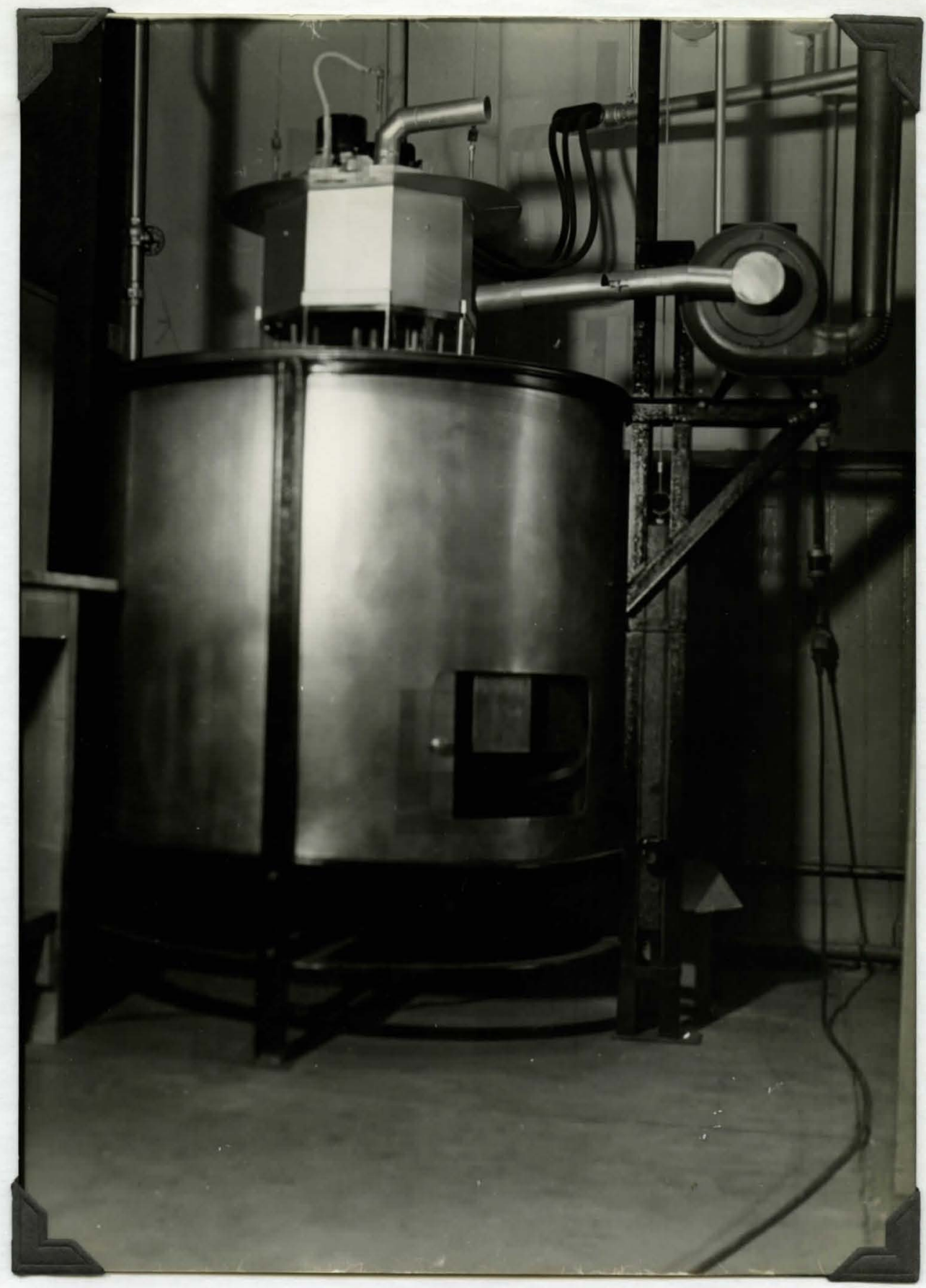

Fig. 2. Accelerated weathering unit. 


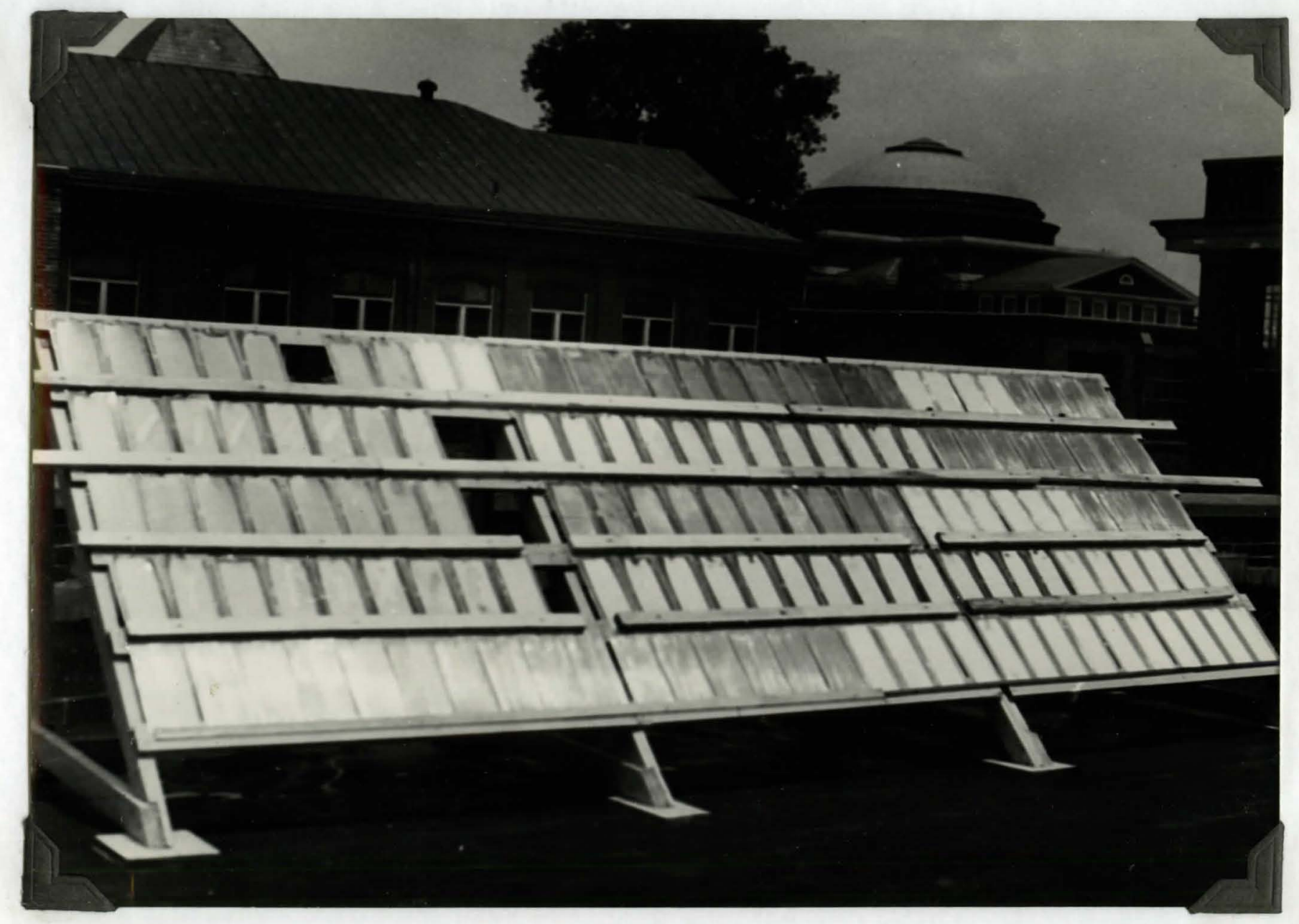

F1g. 3. Outdoor exposuro fence. 
the basement floor of the laboratory building was used for an approximate conetant-temperature, constant-humidity room for conditioning the filme for the elongation tests. The temperature was maintained in the range of $21.1-29.4^{\circ} \mathrm{C}\left(70-85^{\circ} \mathrm{F}\right)$ and the humidity in the range of 54 to $60 \%$ relative humidity. Humidity was controlled by the use of a saturated solution of $\mathrm{Mg}\left(\mathrm{NO}_{8}\right)_{8} \cdot 6 \mathrm{H}_{8} \mathrm{O}$ in an open pan as suggestod by Gardener (7). Such a solution when contained in an air-tight compartment and held at $21.1^{\circ} \mathrm{C}$ $\left(70^{\circ} \mathrm{F}\right)$ will hold the atmosphere of the enclosure around $54 \%$ relam tive humidity.

PILM CUTTING TBMPLATE. A $6 \times 1 \mathrm{~K} 8$ inch bar of cold-rolled tool was polished on one $1 \times 6$ inch face and used as a template for cutting the film strips used in the elongation tests. See Fig. 4. MIOROMETER. A Randall \& stickney dial gage mlcrometer was used in determining the film thickness of the test strips for the olongation tests. Each degree on the dial gage reads 0.001 inch thickness. See Fig. 4. ELONGATION TESTER. A model X-5 scott Teneile Tester manufactured by the Henry L. Scott Co. of Providence, R.I. was used in determining the tensile strength and elongation of the free films. This tester operates at a constant speod of 12 inches per minute and has a double operating capacity of 0 to 2 pounds and 0 to 10 pounds. See. Pig. 5. EXTRACTION APPARATUS: Thirty-six Sohxlet extraction units ar- 


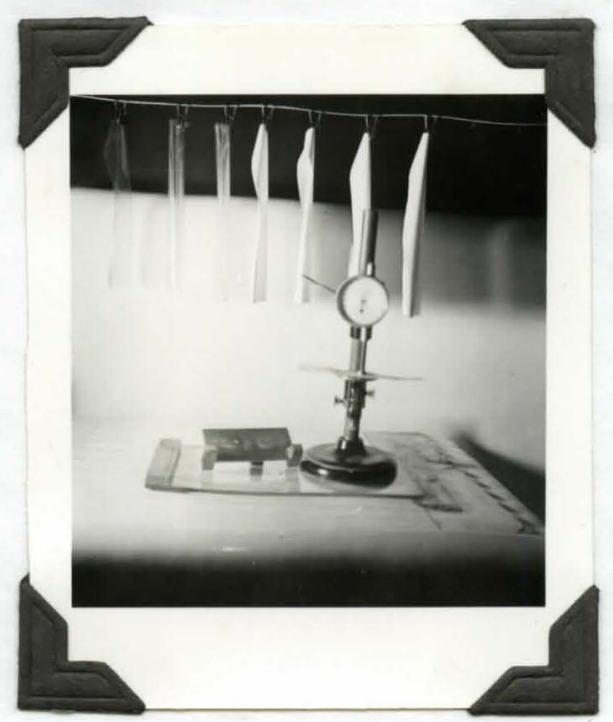

Fig. 4. View showing micrometer on right, doctor blade in center, teel template on left, and stripped films in background. 


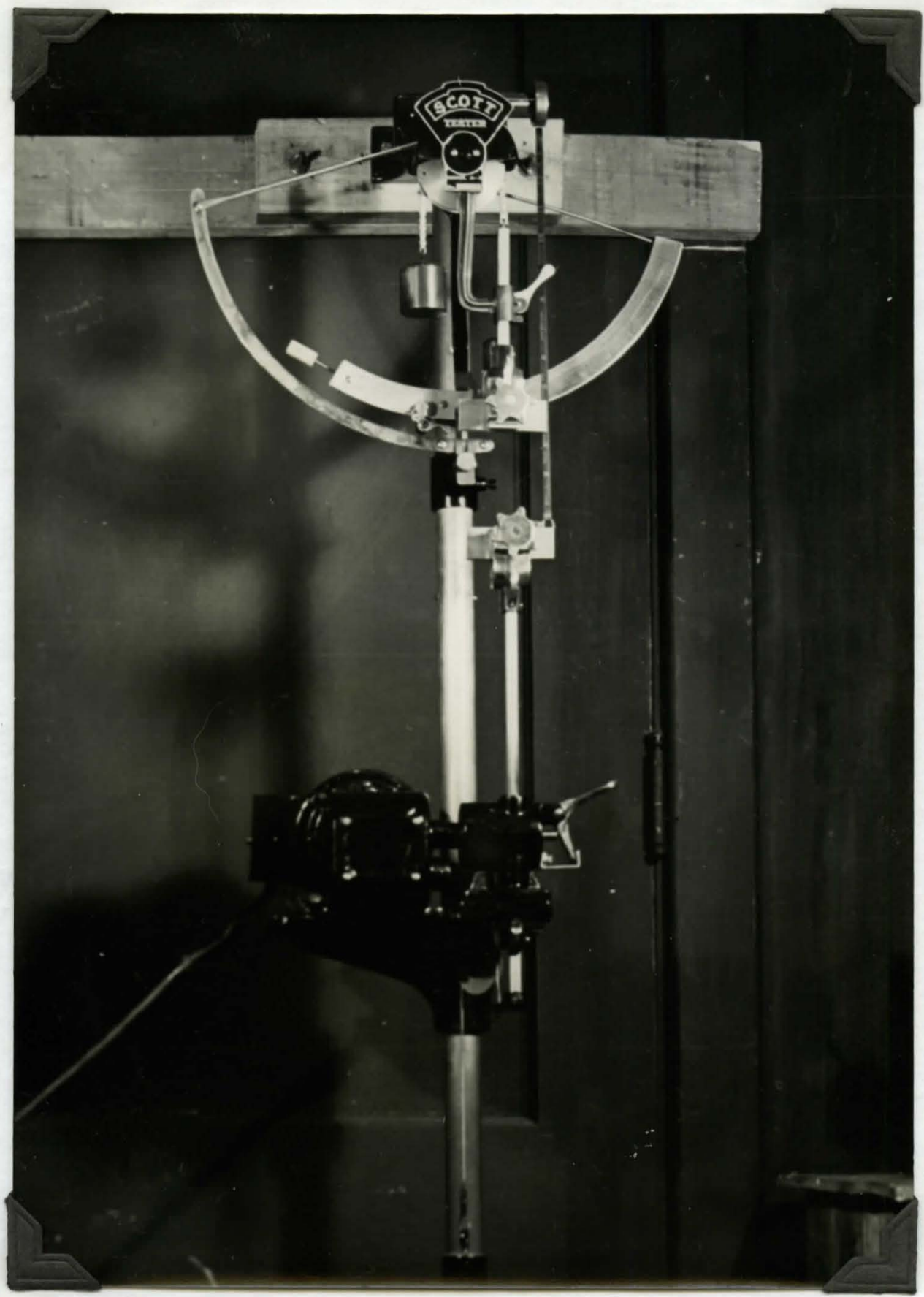

Fig. 5. Tensile tester used in maklng the distensibility tests. 


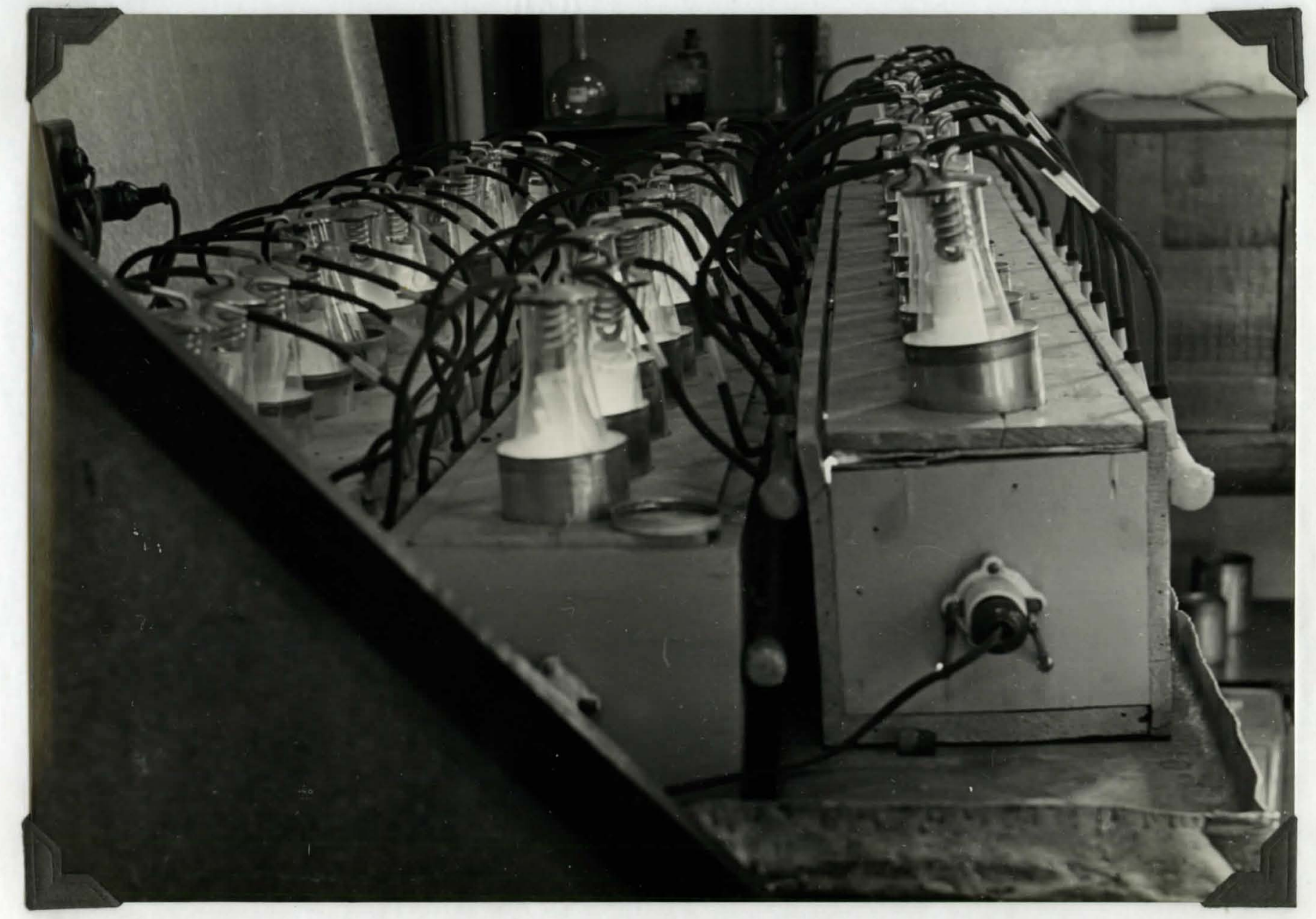

Fig. 6. Extraction units used in extracting the films 
ranged in three batterios of twolve unt te each were used for the film extractions. Each extraction unit consisted of an Erlenmoyer flaok and a motal condeneing coil which was so constructed that it protruded down within the top of the flask. On the bottom of the condensing coll was suepended the characterlstic Sohxlet aphon cup into which was fitted the porous thimble containing the film sample. Each battery was constructed as a long narrow box so as to contain twelve units fitted with holes in the top of the box and twelve 75 watt incandescant lamp heatere fit ted in the box directly under the extraction units. Water for the condeneers was provided by means of two pipes fixed on the outsides of the box, so that the water cooling system operated in parallel. See Fig. 6. EXTRACTION THIMBLES. Whattman extraction thimbles $22 \mathrm{~mm}$ diamoter and $80 \mathrm{~mm}$ long and made of porous parchment paper were used as the recepticles for the film semples in the Sohxlet extraction cups. Each thimble was lined with No. 30 whattwan filter paper in order to protect the thimble for oubsequent uee. Double thicknese thimbles wore used whenever a pigmented film was to be extracted. 
EXPERIMENTALTROCEDURE 
The general experimentel procedure followed in this inrestigation consisted of oating, aging, inspecting, stripping, conditioning, elongating, and extracting the filme produced from the prepared oil, varnish, and onamel formulations: Each stop will be explained. CASTING. Plate glase panels were leveled and a film of water spread over the top ourface. In panels were thoroughly cleaned on both sides with ethyl alcohol and firmly presed onto the wet ted glass so as to produce adhesion between the two. This facilltated a flat and stationary metal surface. All film were cast with 0.01 inch doctor blade which deposited filme drying to uniform thickneses of approximately 0.0025 inch. The straight oll filme dried thicker because of the high solid content. Each film of a particular sample dried to a uniform thickness of \pm 0.0004 inoh. Howerer, due to the differences in ourface tension and the solid content of the various samples the film thickness varied \pm 0.002 inch orer the entire investigation. All films were cast by the same operator who cast with a forward pull on the caster of 18 inches per minute. The films were allowed to dry in a quiet atmosphere for two or three days before the next otop was commenced. Two films of each formulation were prepared at every casting so as to have a complete sot of panele representing every formulation included in every run of the tests which followed. AGING. The panels were trimmed to $3 \frac{1}{4} \times 10$ inches and aged in 
the accelerated weathoring apparatus for a designated number of cycles. Ohanges from one period to another within a cycle were made by hand, however, the schodule for changes was adherred to closely.

INSPECTING. At the end of every cycle each panel was carefully inspocted for chalking, loss of gloss, checking, cracking, and alligatoring. Ohanges in film conditiona wero recorded. Becamse of the difficulty in detecting failure by chalking for the non-chalking pigment used, the first dofintte sign of fatlure noted was of a checking nature. This is the type of failure reforred to in Tables III-VI and in Figs. 7-i6. STRIPPING. After removing a panel from the weathering unit the film was wiped free of water and set in a tilting position with the top end raised about $15^{\circ}$ with the horizontal. A small portion of unprotected tin near the top end of the film was wiped clean and a drop of technical mercury from a modicine droppor placed there. The panel was left in this position overnight allowing the amalgamation to take place. The filmo were then trimmed around the edges of the panel with a razor blade and carefully lifted or stripped free from the panel. The adhesion of films to amalgamated tin is 80 slight that this stripping procoss is quite satisfactory for removing films without olongating them. CONDITIONING. The stripped filme were hung on clips in a constant-temperature, constant-humldity room for 36 or more hours 
permitting them to reach tomperature-humidity equilibrium with the room conditions before testing in the room. ELONGaTIVo. Two film etrips measuring exactly $1 \times 6$ inehes were cut out of each film using a stoel template as pattern and a razor blade for the cutter. The strips were moasured for minimum thickness with a micrometer. The location of all varying thicknesses was noted. The value corresponding to that location in which the film broke was taken as the film thicknoss. The two films for each sample as cast furnishod four atrips per formulation for that particular elongation test. The test performed on each atrip consiated of fastening the film between the upper and lower jaws of the teater, measuring the length of film free to stretch between the jaws, reading the inftial load on the load scale, applying the load by means of the atarter, atopping the loading imediately after the break occurred, remeasuring the length between the jaws, and reading the final load on the load scale. From the tensile strength and percent elongation data thas obtained, the calculated values for the satisfactory pulls were averaged and the averages taken as the distensibility values. EXTRACTING. The filmo were then cut up into fine bits (and ground in a mortar with a pestal when possible) in preparation for extraction with acetone. Before the flne film particles were placed in the extraction thimbles it was necessary to extract the thimbles empty permitting them to attain a fibre free and insoluble con- 
dition, then heat them in an oren at $105^{\circ} \mathrm{O}\left(221^{\circ} \mathrm{F}\right)$ for two hours, 0001 them to room temperature in a dessicator, and weigh them for tare woight. Samples of about 2 grams in woight were carefully placed in the thimbles and therein extracted for approximately two woeks time. soveral times during the extraction period the thimbles were dried, cooled, and weighed in order to determine the progress of the extraction. All weighings nere made with the thimble in a welghing bottle on an analytical weighing balance. Two empty thimbles were extracted, heated, cooled, and welghed as blank thimbles in every sot of samples extracted. This was done so to reduce incurring errors resulting from any uncontrollable weight changes during the conditioning and weighing of the thimbles. The average: of the changes in weight of the blanks over their original weights was taken as the blank correction for that particular weighing and was applied to all sample weights in calculating the percent of sample unextrected. 
DA I A D RESULTS 
The tensile strength, percent elongation, and percent unextractible date for the oil, varnish, and enamel filme are given in Tables III-VI. Table VII gives the extraetion data for the congo resin films. Table VIII gives the ratio in which the oils and resin were used and the percent unextractible when fallure occurs.

The tensile strength of a film was obtained by dividing the ultimate load required for the break by the film thicknoes. The films were cut 1 inch wide, consequently, the values are reported as pounds per square inch. Percent elongation was calculated by dividing the difference of the inftial length and multiplying by 100. It should be noted hene that the hand operated relesse on the tensile tester made it impossiblo to stop the moasurIng mochaniom instantaneously with the break, consequently, all readings are subject to a positive error of 0.07 inch or lese. This error amounts to about $2 \%$ or 1088. Percent unextractiblo was calculated by dividing the dry insoluble portion of the film by the weight of original dry sample and multiplying by 100.

The astericks in the tables and the short perpendicular Iines croesing the curves in the figures indicate the approximate points of definite film failure as determined by inepection.

Figures 7-17 are curves obtained by plotting the percent of film unextractible versus age and vereus percent elongation. No curves were drawn showing a relation of tonsile strength. 
TABLE III

Dictensibility and Percent Unoxtractible of Iinseod Varnishes

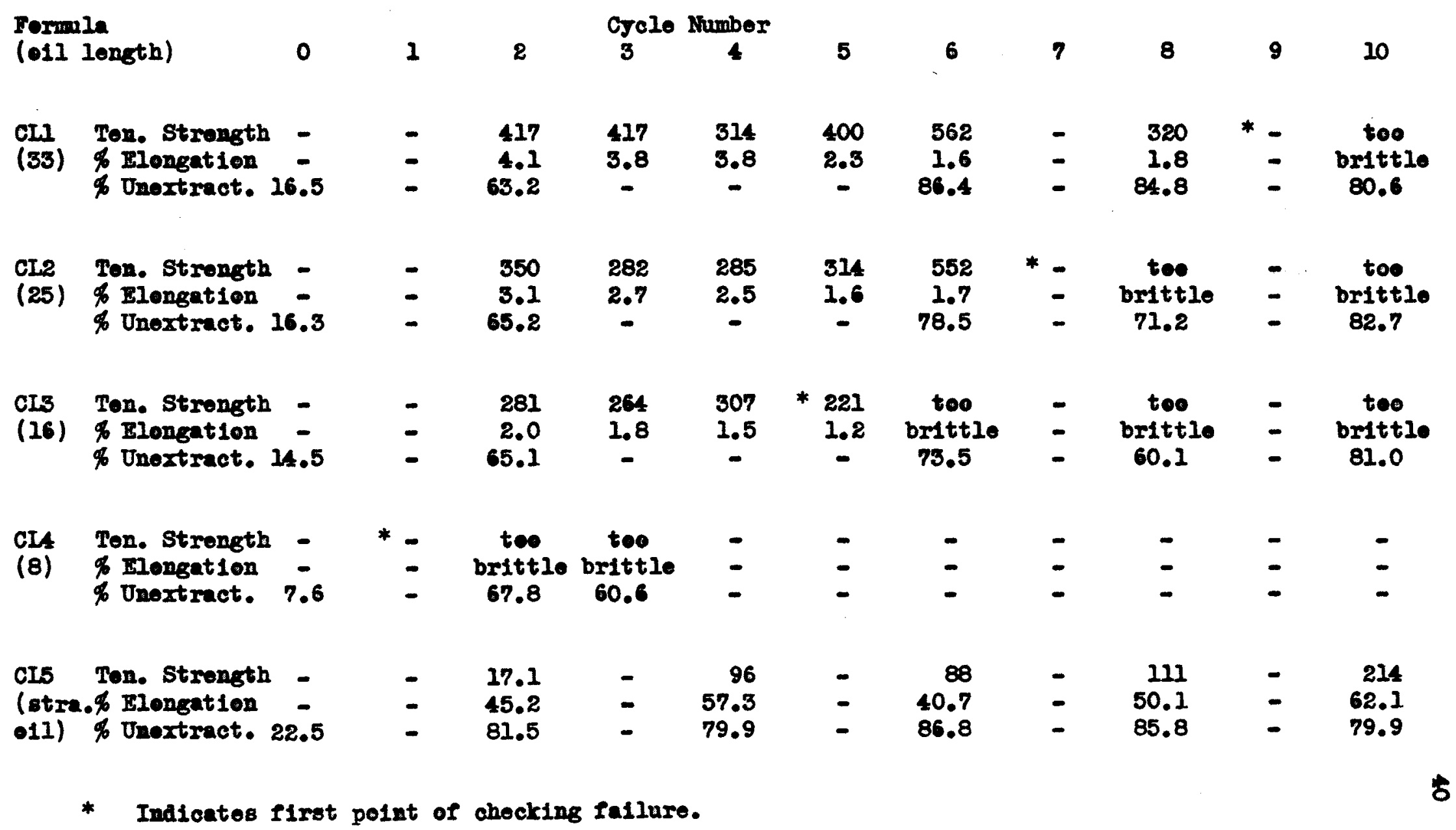


TABLE IV

Distensibility and Percent Onextractible of Tung Varnishes

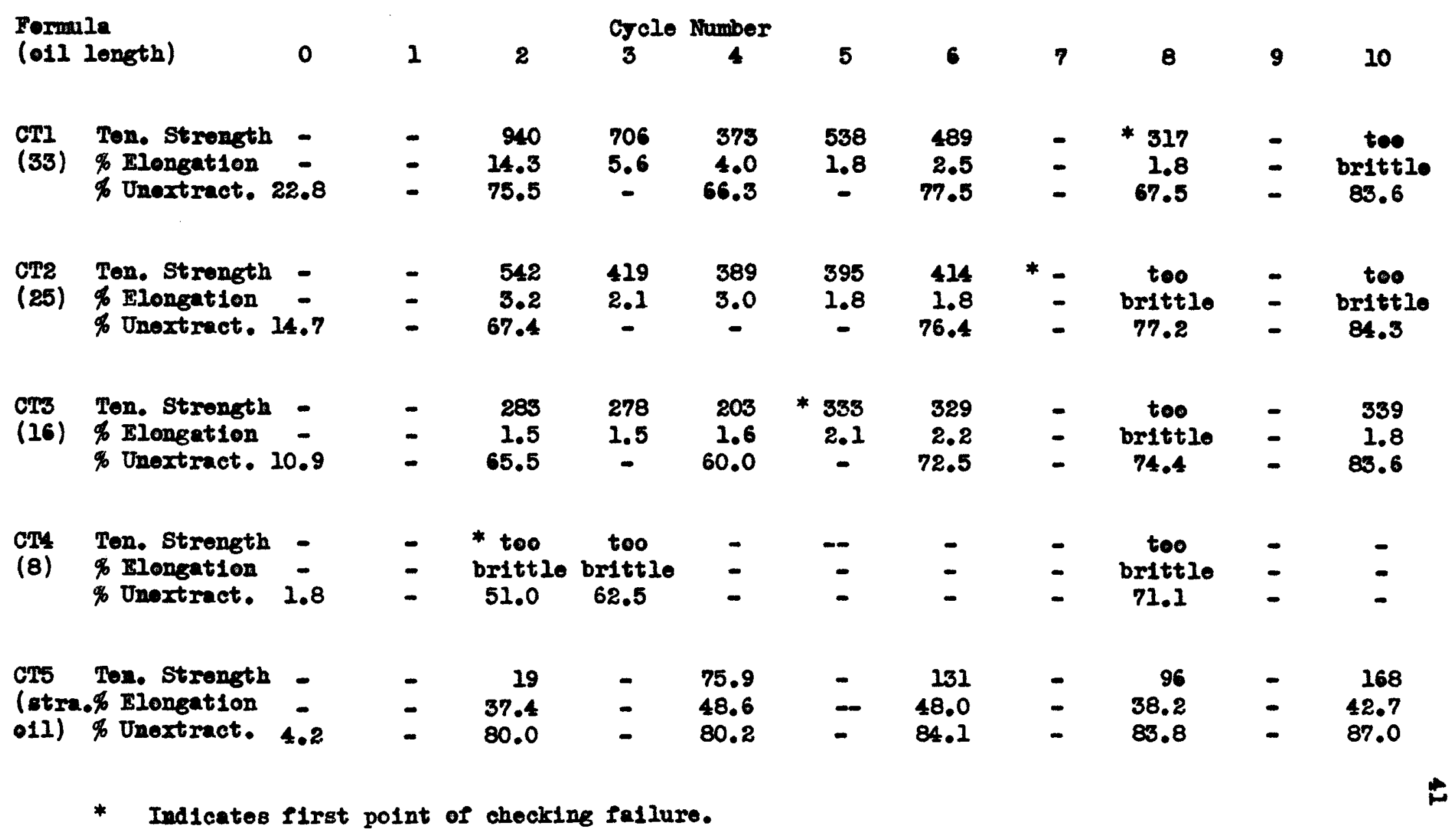


TABLE V

Distonsibility and Porcent Onoxtractible of IInseod Inomols

\begin{tabular}{|c|c|c|c|c|c|c|c|c|c|c|c|c|}
\hline $\begin{array}{l}\text { Porma } \\
\text { lo11 }\end{array}$ & length) & 0 & 1 & 2 & ${ }_{3}^{\text {Csclo }}$ & $\begin{array}{c}\text { Number } \\
4\end{array}$ & 5 & 6 & 7 & 8 & 9 & 10 \\
\hline $\begin{array}{l}\text { DIPI } \\
(33)\end{array}$ & $\begin{array}{l}\text { Ten. Strength } \\
\text { \% Elongation } \\
\text { \% Unextract. } 55\end{array}$ & $\frac{-}{5.7}$ & - & $\begin{array}{r}418 \\
21.4 \\
75.7\end{array}$ & $\begin{array}{l}320 \\
34.2 \\
-\end{array}$ & $\begin{array}{r}347 \\
11.0 \\
72.7\end{array}$ & $\begin{array}{l}463 \\
2.7 \\
-\end{array}$ & $\begin{array}{r}500 \\
3.1 \\
82.7\end{array}$ & - & $\begin{array}{r}430 \\
2.8 \\
84.7\end{array}$ & - & $\begin{array}{r}810 \\
4.4 \\
86.3\end{array}$ \\
\hline $\begin{array}{l}\text { DLP2 } \\
(25)\end{array}$ & $\begin{array}{l}\text { Ten. Strength } \\
\text { \% Flongation } \\
\text { \% Unextract. } 54\end{array}$ & $\stackrel{-}{4.1}$ & $\dot{-}$ & $\begin{array}{r}526 \\
13.1 \\
77.6\end{array}$ & $\begin{array}{r}329 \\
24.0 \\
-\end{array}$ & $\begin{array}{r}315 \\
10.7 \\
-\end{array}$ & $\begin{array}{l}312 \\
1.8 \\
-\end{array}$ & $\begin{array}{r}493 \\
2.8 \\
78.5\end{array}$ & * & $\begin{array}{l}\text { too } \\
\text { brittio } \\
72.7\end{array}$ & - & $\begin{array}{r}691 \\
3.1 \\
88.3\end{array}$ \\
\hline $\begin{array}{l}\text { DLP3 } \\
(16)\end{array}$ & $\begin{array}{l}\text { Ten. Strength } \\
\text { \% Fiongation } \\
\text { \& Unextract. } 49\end{array}$ & $\frac{-}{9.5}$ & $\begin{array}{l}- \\
-\end{array}$ & $\begin{array}{r}217 \\
1.8 \\
71.0\end{array}$ & $\begin{array}{r}221 \\
2.6 \\
73.8\end{array}$ & $\begin{array}{l}- \\
-\end{array}$ & $\begin{array}{l}* \text { too } \\
\text { brettlo } \\
84.5\end{array}$ & $\begin{array}{l}- \\
-\end{array}$ & $\overline{-}$ & $\begin{array}{l}\text { too } \\
\text { brittlo } \\
65.6\end{array}$ & - & $\begin{array}{r}319 \\
1.8 \\
84.0\end{array}$ \\
\hline $\begin{array}{l}\text { DLP4 } \\
(8)\end{array}$ & $\begin{array}{l}\text { Ton. Strength } \\
\text { \% Elongation } \\
\text { \% Unextract. } 43\end{array}$ & $\frac{-}{3.1}$ & $\begin{array}{c}\text { too } \\
\text { brittle } \\
61.3\end{array}$ & $\begin{array}{l}* \text { too } \\
\text { britt } 10 \\
58.5\end{array}$ & $\begin{array}{c}\text { too } \\
\text { brittlo } \\
65.6\end{array}$ & $\ddot{-}$ & $\begin{array}{l}- \\
-\end{array}$ & $\begin{array}{l}- \\
-\end{array}$ & - & $\dot{-}$ & - & - \\
\hline $\begin{array}{l}\text { DIPS } \\
\text { (p1E. } \\
\text { o11) }\end{array}$ & $\begin{array}{l}\text { Ton. Strongth } \\
\text { \% Elongation } \\
\text { \% Unextrect. } 48\end{array}$ & $\frac{-}{8.3}$ & - & $\begin{array}{l}110 \\
60.6 \\
79.7\end{array}$ & - & $\begin{array}{r}110 \\
53.4 \\
81.4\end{array}$ & - & $\begin{array}{r}155 \\
55.8 \\
86.5\end{array}$ & - & $\begin{array}{r}139 \\
50.6 \\
87.1\end{array}$ & - & $\begin{array}{r}187 \\
44.5 \\
89.7\end{array}$ \\
\hline
\end{tabular}

* Indicates first point of checking fallur. 
TABIE VI

Diatensibility and Percent Unextractible of Tung Bnomelo

\begin{tabular}{|c|c|c|c|c|c|c|c|c|c|c|c|c|}
\hline $\begin{array}{l}\text { Formu } \\
\text { lo1I }\end{array}$ & $\begin{array}{l}\text { Ila } \\
\text { length) }\end{array}$ & 0 & 1 & 2 & $\begin{array}{c}\text { Crele } \\
3\end{array}$ & $\begin{array}{c}\text { Number } \\
4\end{array}$ & 5 & 6 & 7 & 8 & 9 & 10 \\
\hline $\begin{array}{l}\text { DIPI } \\
(33)\end{array}$ & $\begin{array}{l}\text { Ten. Strongth } \\
\text { \% Elongat 1on } \\
\text { \% Unextract. } 39\end{array}$ & $\frac{-}{9.2}$ & $\ddot{-}$ & $\begin{array}{r}601 \\
19.5 \\
73.2\end{array}$ & $\begin{array}{r}535 \\
60.9 \\
-\end{array}$ & $\begin{array}{r}400 \\
16.2 \\
75.0\end{array}$ & $\begin{array}{l}464 \\
4.4 \\
-\end{array}$ & $\begin{array}{r}629 \\
9.4 \\
84.6\end{array}$ & * & $\begin{array}{r}642 \\
3.1 \\
79.7\end{array}$ & $\begin{array}{l}- \\
-\end{array}$ & $\begin{array}{r}1152 \\
6.3 \\
90.4\end{array}$ \\
\hline $\begin{array}{l}\text { DIPR } \\
(25)\end{array}$ & $\begin{array}{l}\text { Ten. Strongth } \\
\text { \% Elongation } \\
\text { \& Unoxtract. } 54\end{array}$ & - & $\begin{array}{l}- \\
-\end{array}$ & $\begin{array}{r}609 \\
5.5 \\
75.2\end{array}$ & $\begin{array}{r}406 \\
23.3 \\
-\end{array}$ & $\begin{array}{c}349 \\
3.4 \\
-\end{array}$ & $\begin{array}{c}413 \\
3.9 \\
-\end{array}$ & $\begin{array}{r}499 \\
3.4 \\
79.0\end{array}$ & $\begin{array}{l}- \\
-\end{array}$ & $\frac{-}{79.8}$ & $\begin{array}{l}- \\
-\end{array}$ & $\begin{array}{r}1018 \\
3.6 \\
88.2\end{array}$ \\
\hline $\begin{array}{l}\text { DIP3 } \\
(16)\end{array}$ & $\begin{array}{l}\text { Ton. Strength } \\
\text { of Elongation } \\
\text { क Unextract. } 54\end{array}$ & - & $\begin{array}{l}- \\
-\end{array}$ & $\begin{array}{r}187 \\
2.0 \\
69.7\end{array}$ & $\begin{array}{c}298 \\
5.9 \\
-\end{array}$ & $\begin{array}{l}242 \\
2.1 \\
-\end{array}$ & $\begin{array}{l}235 \\
1.4 \\
-\end{array}$ & $\begin{array}{r}295 \\
1.8 \\
81.2\end{array}$ & - & $\begin{array}{r}224 \\
1.7 \\
70.2\end{array}$ & - & $\begin{array}{r}300 \\
1.9 \\
87.2\end{array}$ \\
\hline $\begin{array}{l}\text { DTP4 } \\
(8)\end{array}$ & $\begin{array}{l}\text { Ten. Strength } \\
\text { \% Elongat1on } \\
\text { \% Unextract. } 45\end{array}$ & $\overline{-}$ & $\begin{array}{c}\text { too } \\
\text { brittlo } \\
67.0\end{array}$ & $\begin{array}{l}\text { too } \\
\text { brittlo } \\
62.2\end{array}$ & $\begin{array}{c}\text { too } \\
\text { brittle } \\
72.4\end{array}$ & $\begin{array}{l}- \\
-\end{array}$ & $\begin{array}{l}- \\
-\end{array}$ & $\begin{array}{l}- \\
-\end{array}$ & - & $\begin{array}{l}- \\
-\end{array}$ & - & - \\
\hline $\begin{array}{l}\text { DIP5 } \\
\text { (p1g. } \\
\text { o11) }\end{array}$ & $\begin{array}{l}\text { Ton. Strength } \\
\text { \& Elongation } \\
\text { of Unextract. } 35\end{array}$ & - & $\begin{array}{l}- \\
-\end{array}$ & $\begin{array}{r}128 \\
35.5 \\
85.7\end{array}$ & $\begin{array}{l}- \\
-\end{array}$ & $\begin{array}{r}118 \\
30.8 \\
87.4\end{array}$ & $\begin{array}{l}- \\
-\end{array}$ & $\begin{array}{l}175 \\
38.3 \\
86.7\end{array}$ & $\begin{array}{l}- \\
-\end{array}$ & $\begin{array}{r}199 \\
40.5 \\
85.0\end{array}$ & $\begin{array}{l}- \\
-\end{array}$ & $\begin{array}{r}330 \\
45.3 \\
90.5\end{array}$ \\
\hline
\end{tabular}

* Indicates first point of checking fallure. 
TABLE VII

Extraction of Congo Resin

Oycle No.

Percent Unextractible

0

22.0

1

56.2

2

63.0

3

4

63.6

5

66.4

6

54.3 


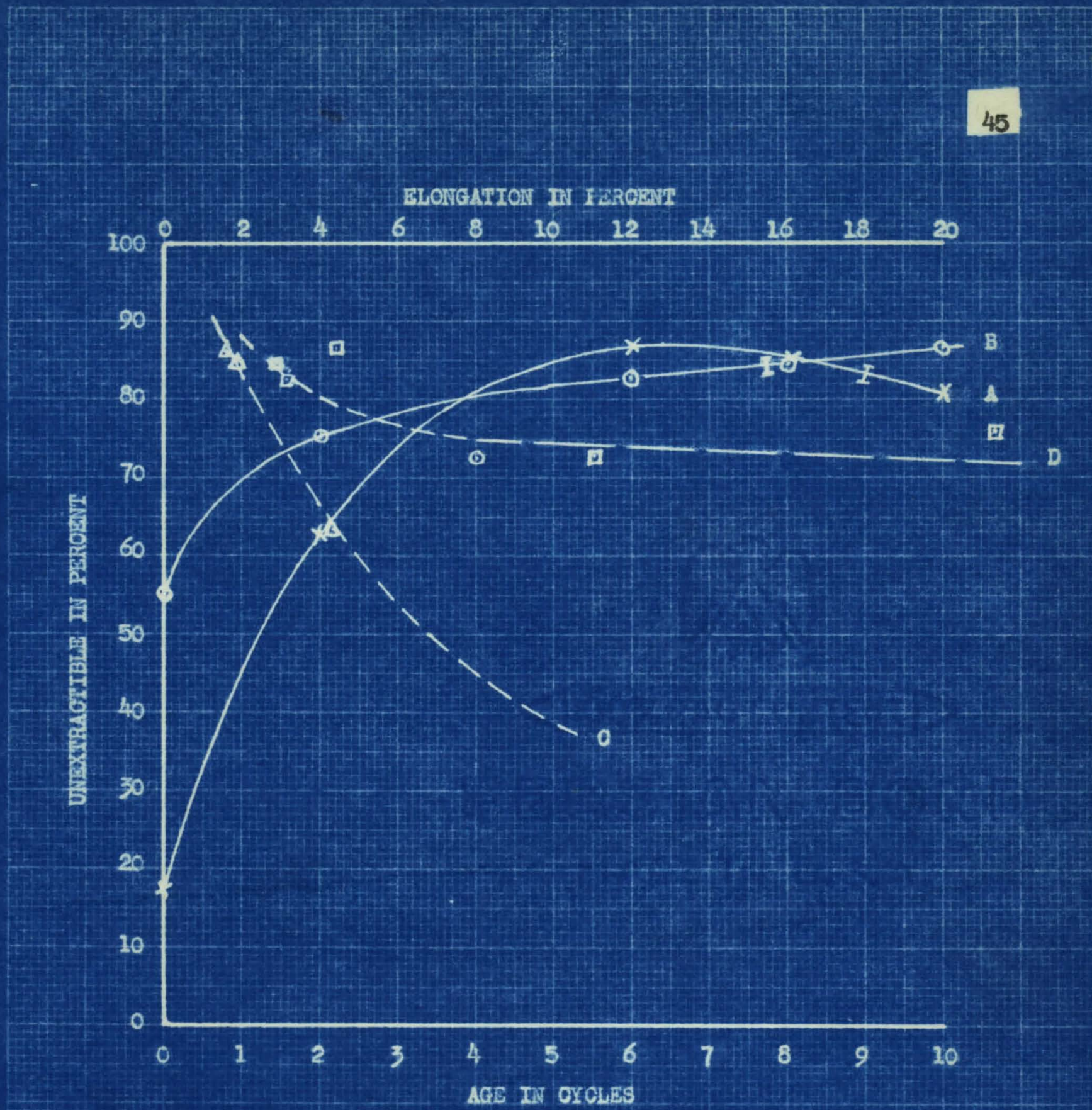
A Jnextractible va Abe - 33 gal. varnioh
B Unoxtractible va Ago $-33 \mathrm{gal}$. onamel
C Unoxtractible vs Elongation - 33 gal, varnioh
D Unextractible ra Blongation - $33 \mathrm{gal}$, onamel

Hotes I indioates point at which definite fallure first appeared

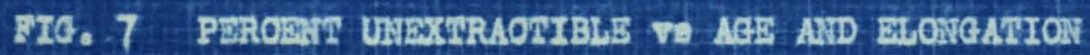

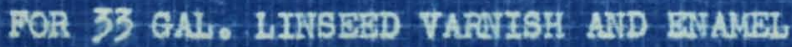




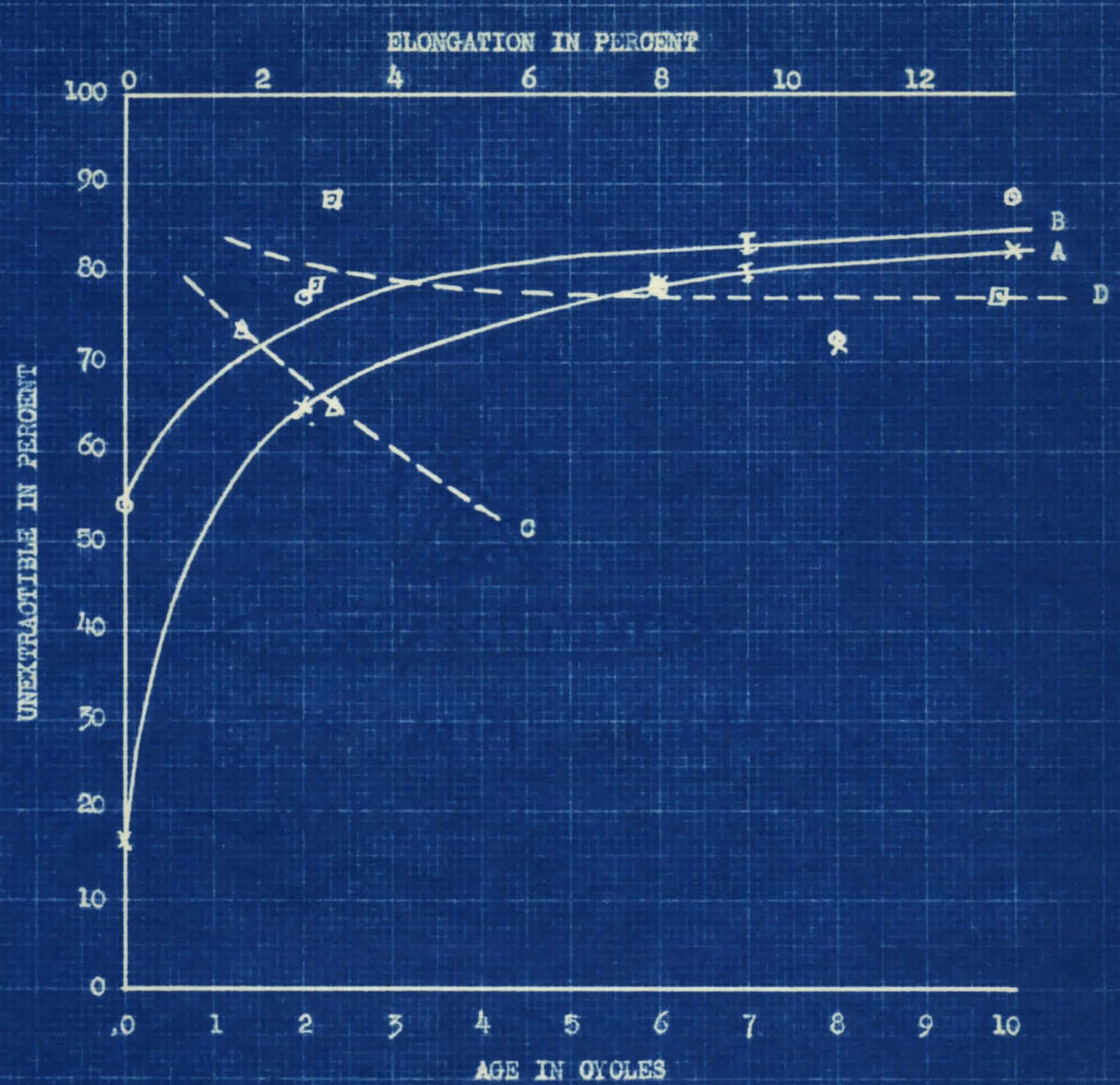
A Unextractible vo Age - 25 gal。 varnioh
B. Unextraot1ble vo Age - $25 \mathrm{gal}$. onamel
- Unextraotible ve Blongation - $25 \mathrm{gal}$. varnish
D Unextractible ve Blongation - 25 gal. onamel
Notes I Indicates point at which defintte fallure first appegred

FTG. 8 PERGENT ENEXTRAGTIBLS VS AGE ATD BLONGATIOE FOR 25 GH. LTISESD TARISH ARD BHAYGL 


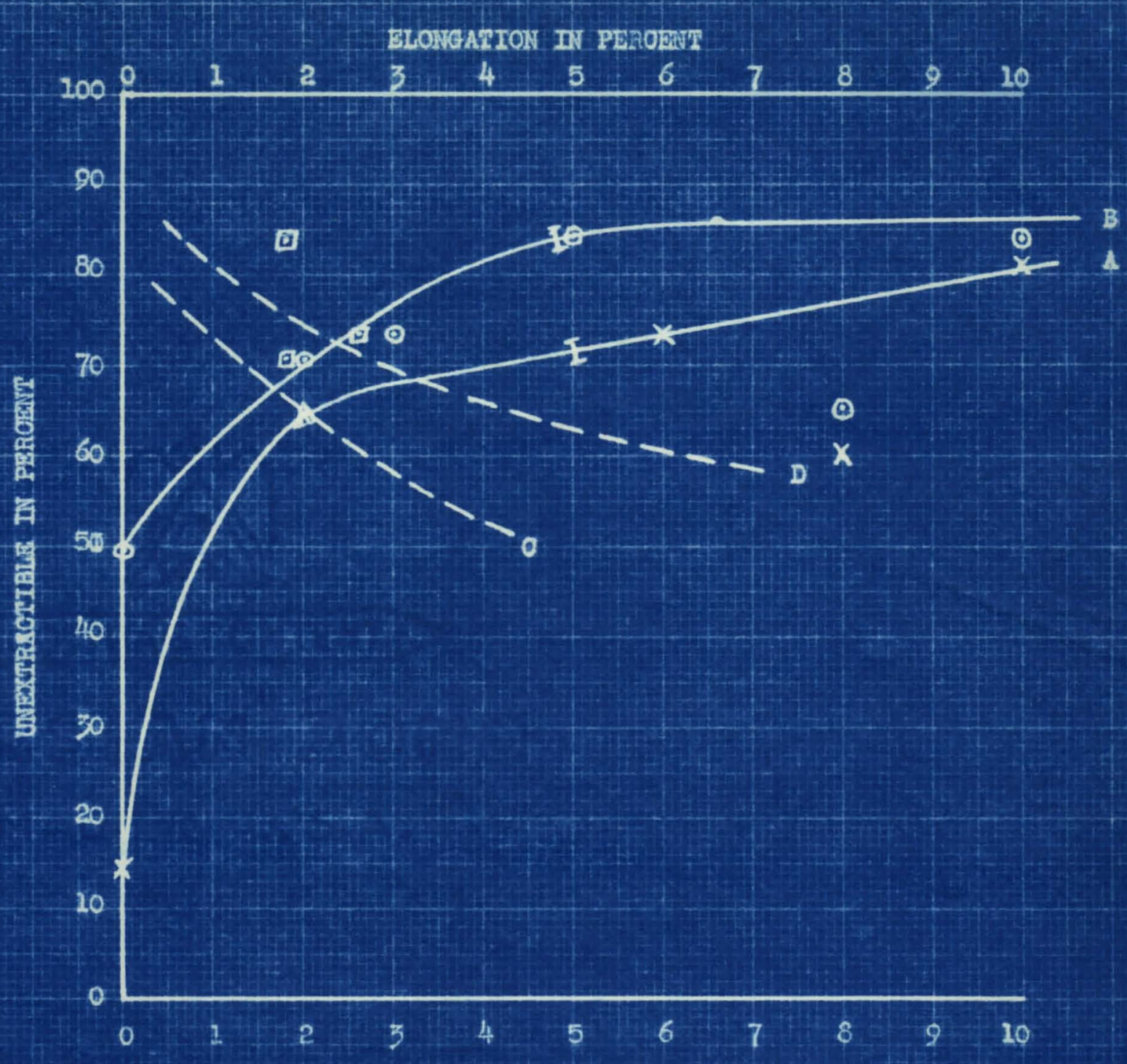

AGE II OXOLES

A Unextractible vo Ago - $16 \mathrm{gal}$. varnish

B Unextractible ve Age - 16 gal. onamal

0 Unextraotible ve Blongation - $16 \mathrm{gal}$ raraleh

D Unextraatiblo va Blongatlon - 16 gal enamel

Notes I Indleates polnt at which definite fallure first appeared

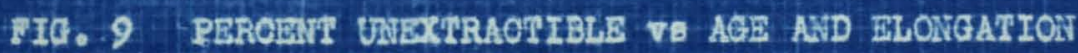
FOR 16 GAL. HIMSBED VARTISH AND ENAIIL 


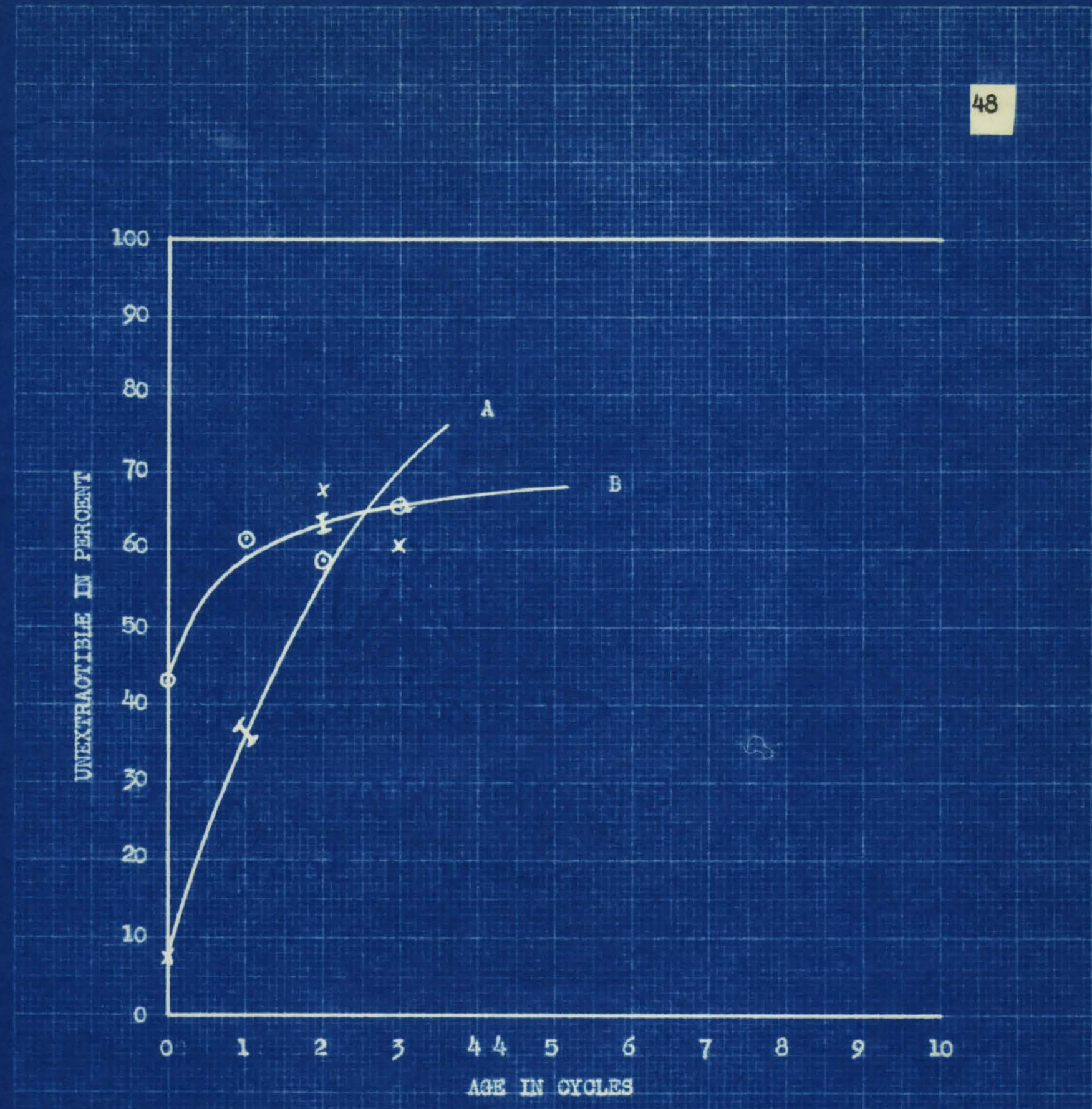
A $8 \mathrm{gal}$. vamish
B 8 gal. enamel

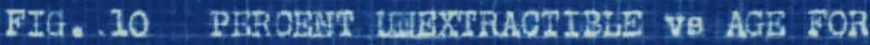

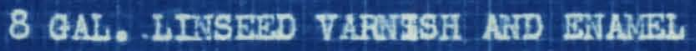




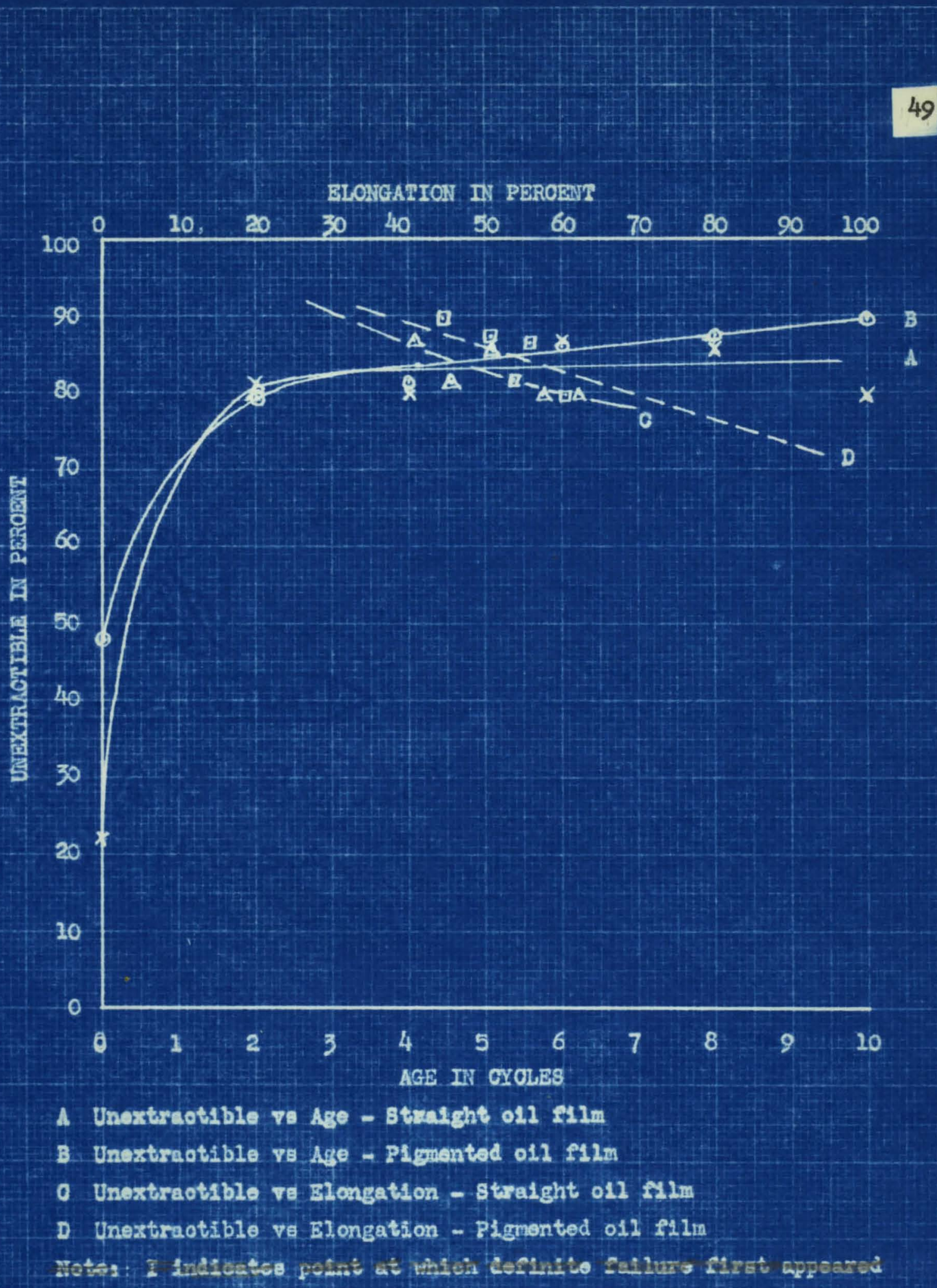

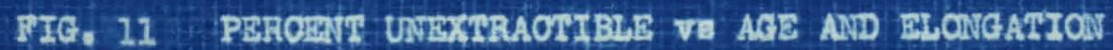
EOR SWRATOHT LEUSMED OL BILMS 


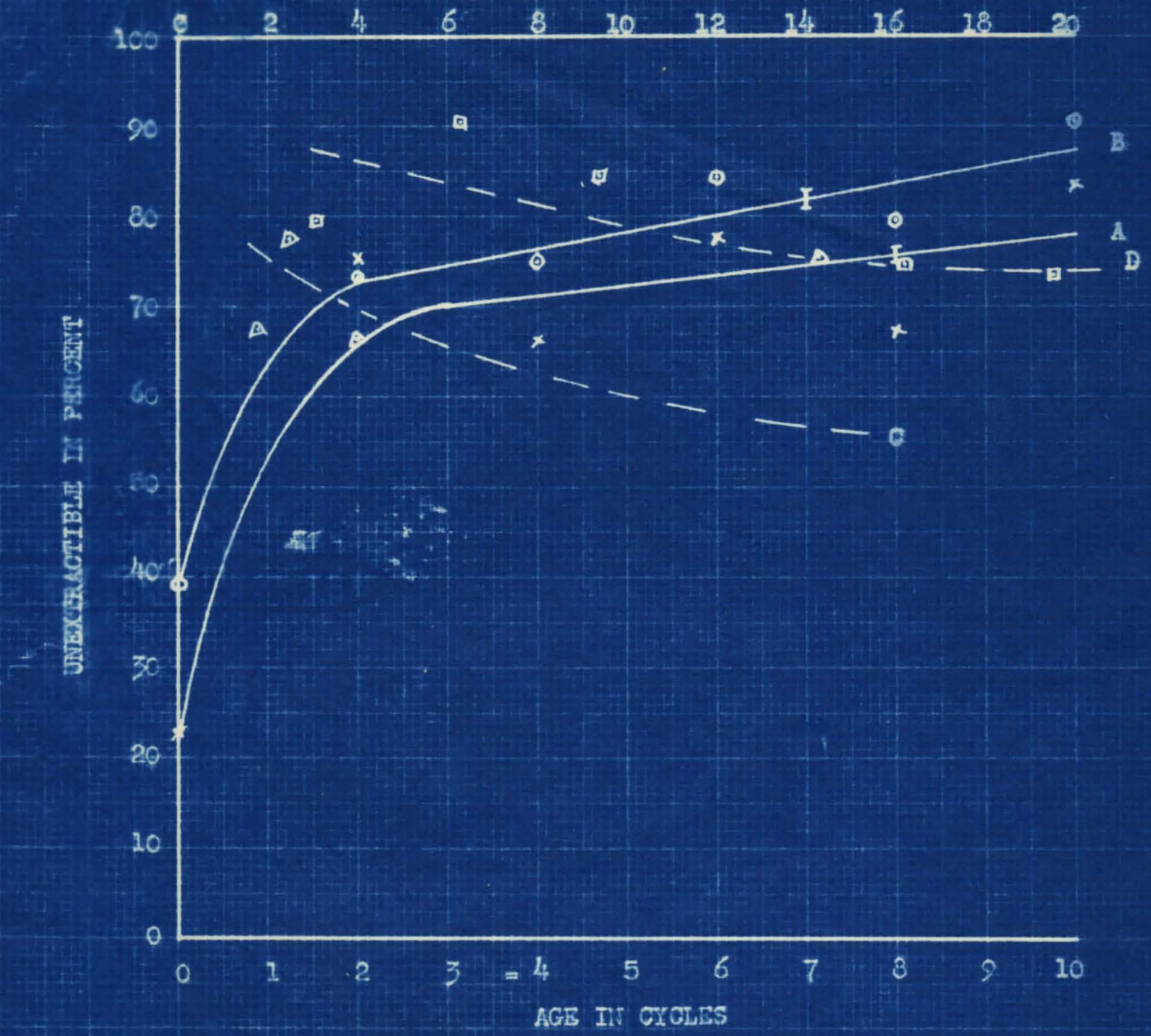

A Unextractible vs Age - $33 \mathrm{gal}$. varnish

B Unextractíble va ABO - $33 \mathrm{gal}$. enamol

a Unextractible rs Elongation - $33 \mathrm{gal}$. ramish

D Unextractíbla vB Blongation - 33 gal. engrael

Notes I Indicates point at which deilinite fallure first appeared

FIG. 12 PERGBNT UABXXYRAOTIBLE VO AGE AND BLOMGATION BOR 33 GALE WUIG TAROISH AND ENAMBL 


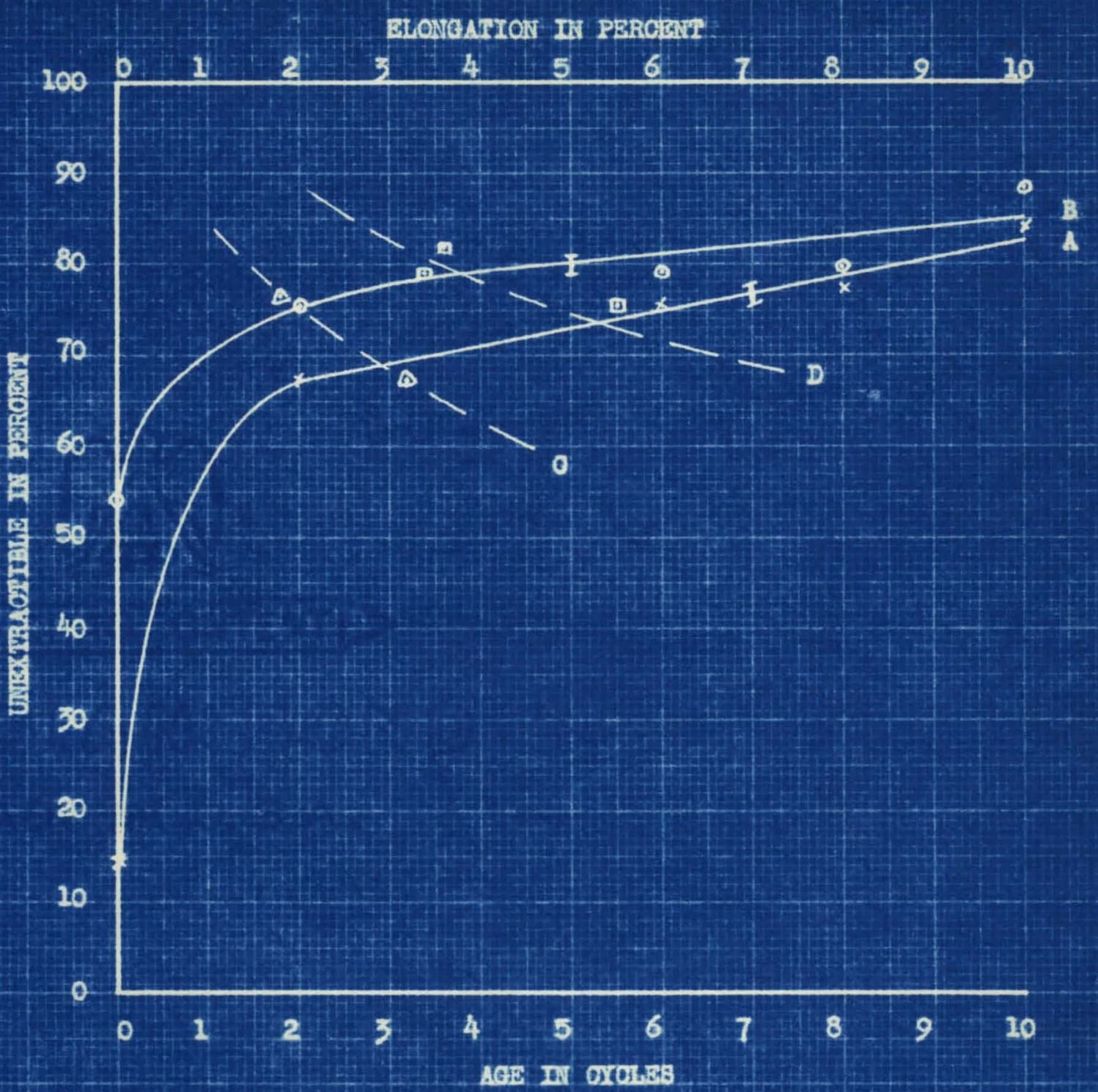

A therthaotsble ve Aso - 25 gal. rantoh

B. Unextractsble to tse - 20 gal. onanal

0 Unextrastiblo vo Elongation - $20 \mathrm{gal}$. vamioh

D Jnexträctible vo siongation- 20 gal. enamel

Iroter. I Indloates point at whioh doflnite fallure flrst appoegred

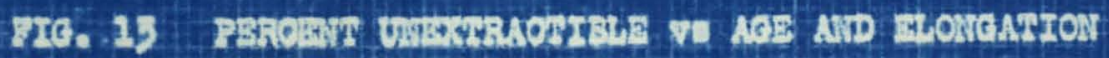

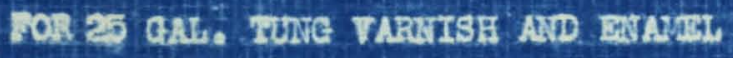




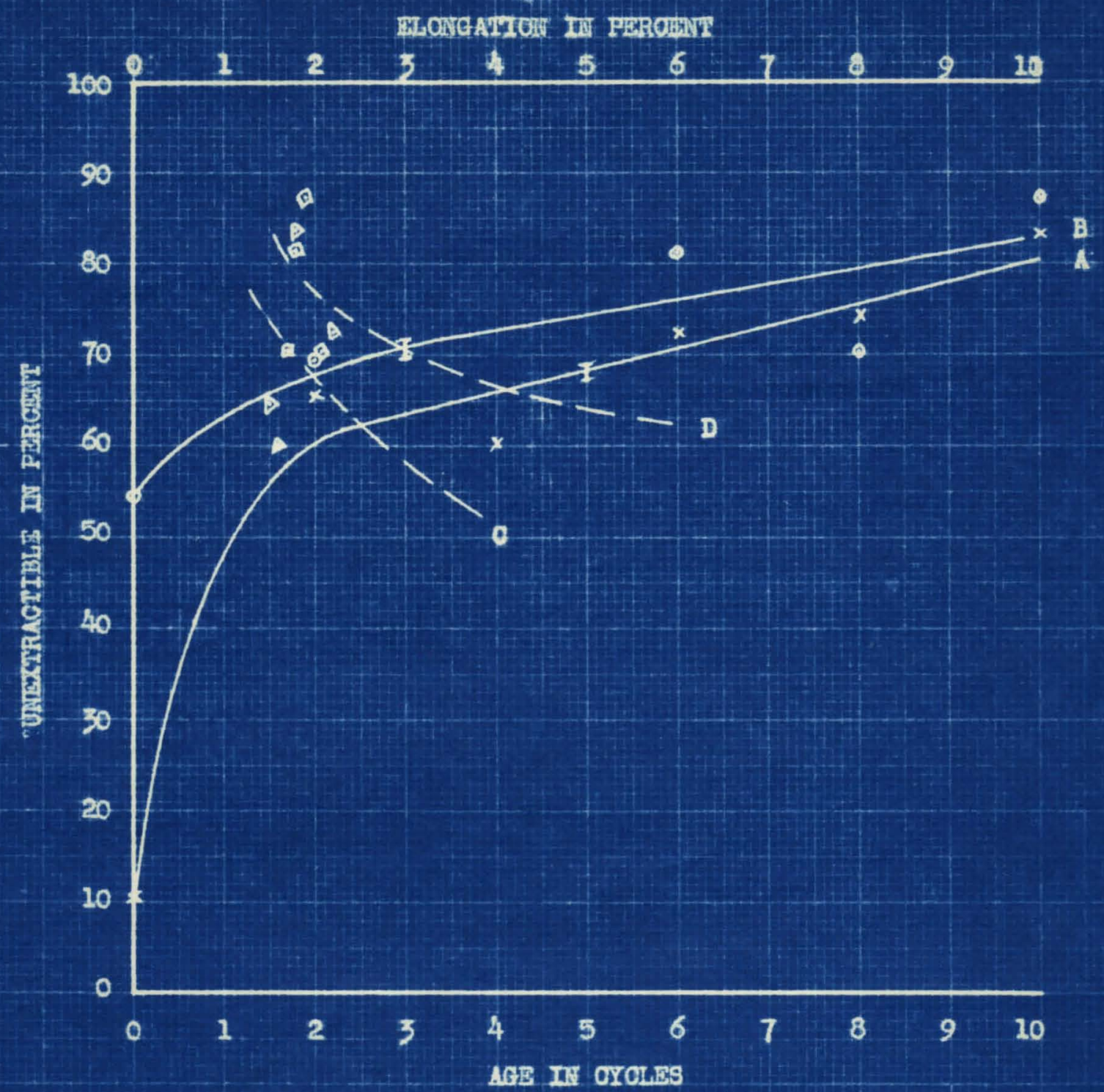

A Enertractible $\mathrm{rs}$ Age - $16 \mathrm{gal}$. vamish

B Enestractible vs Age - 16 gal, enamel

- Inextractible vs 1 longation - $16 \mathrm{gal}$, vamish

D Dnextractible rs 5longation - 16 gal. mamel

lioter I indioatos point at whish definite falluxe first appeared

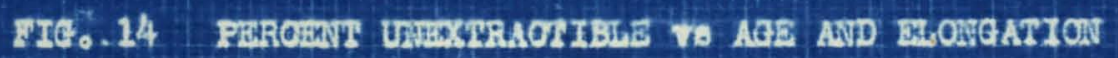
FOR 16 GAL. TUMA VARTBSH ADD BRAMRL 


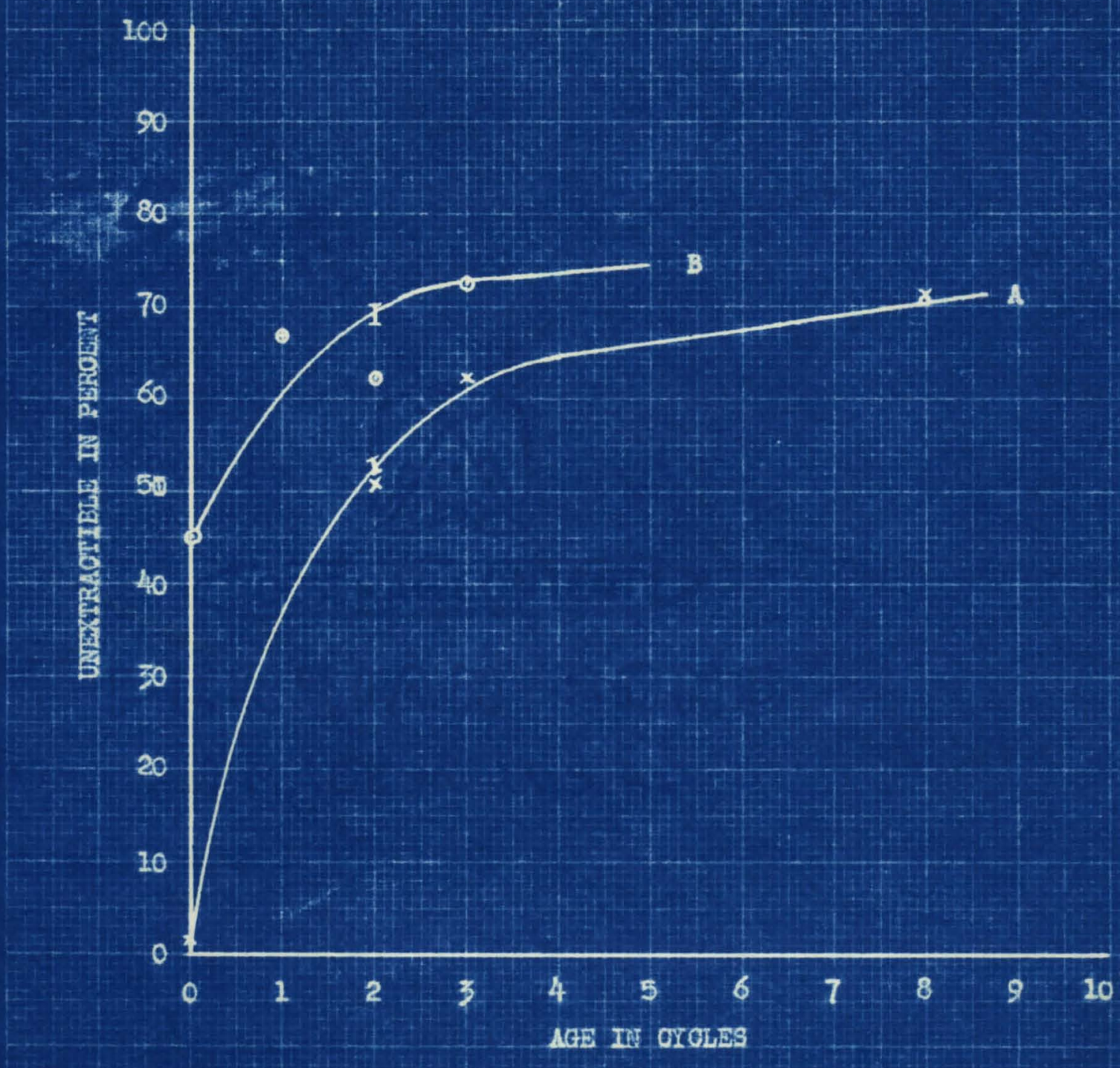
4 \& gal. varnioh
B. 8 gal. enarel

PIG. 15 PERQEAT GXEXTRACTIBLE VB AGE FOR 8 GAL. TUMA VARTISH AND BRTMST 


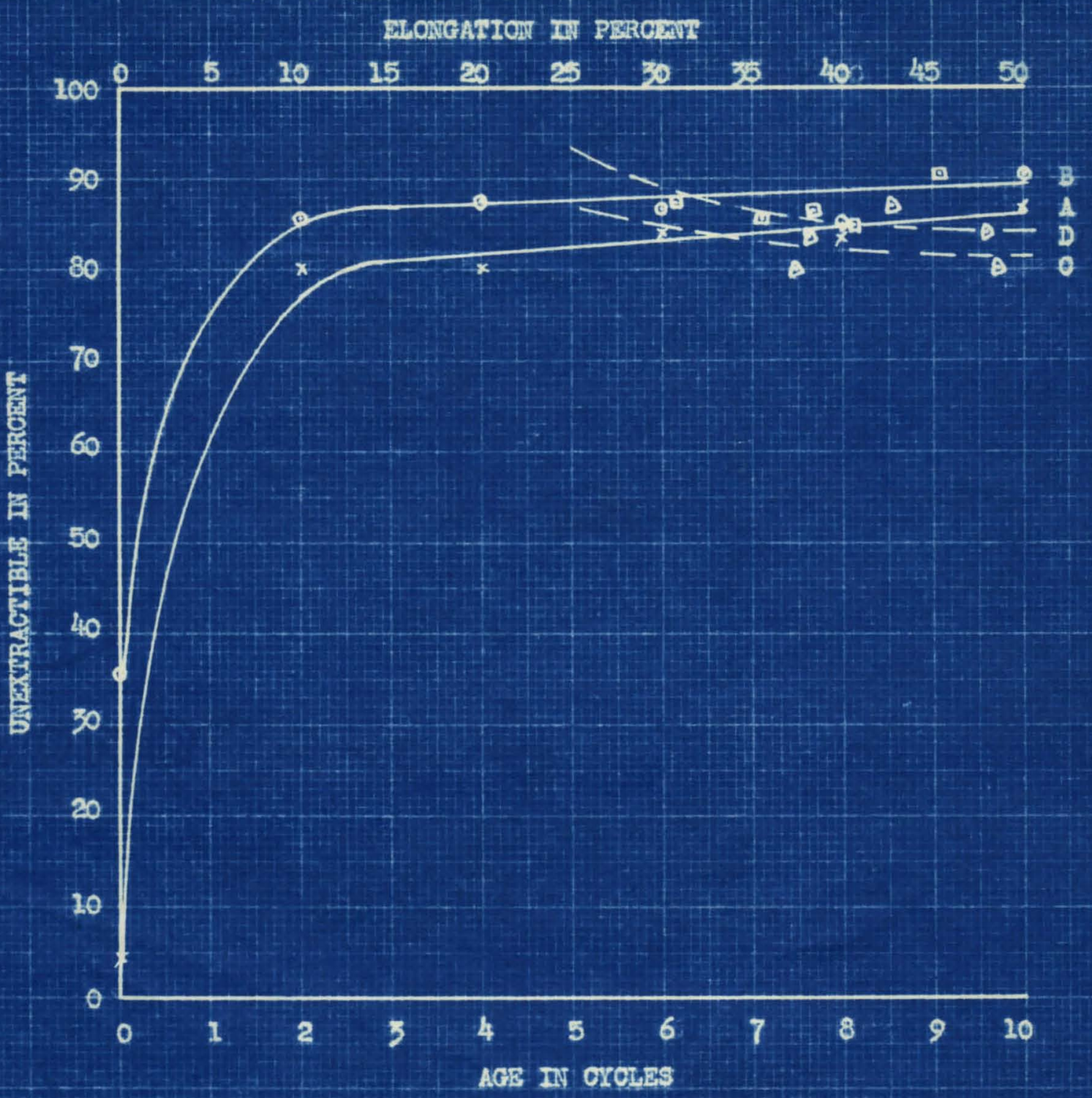

A Unextraotiblo v8 Ago - stralght otl fllm

B Vnextrinatiblo v8 Age - Plgmented ofl fllm

- Unextractible vs Elongation - stratght oll flim

D. Unextractible v8 Blongation - Plgmented 011 fllin

Notos I indieates point at which definito fallure first appeared

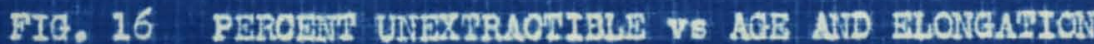

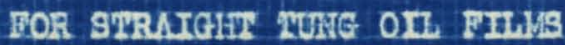




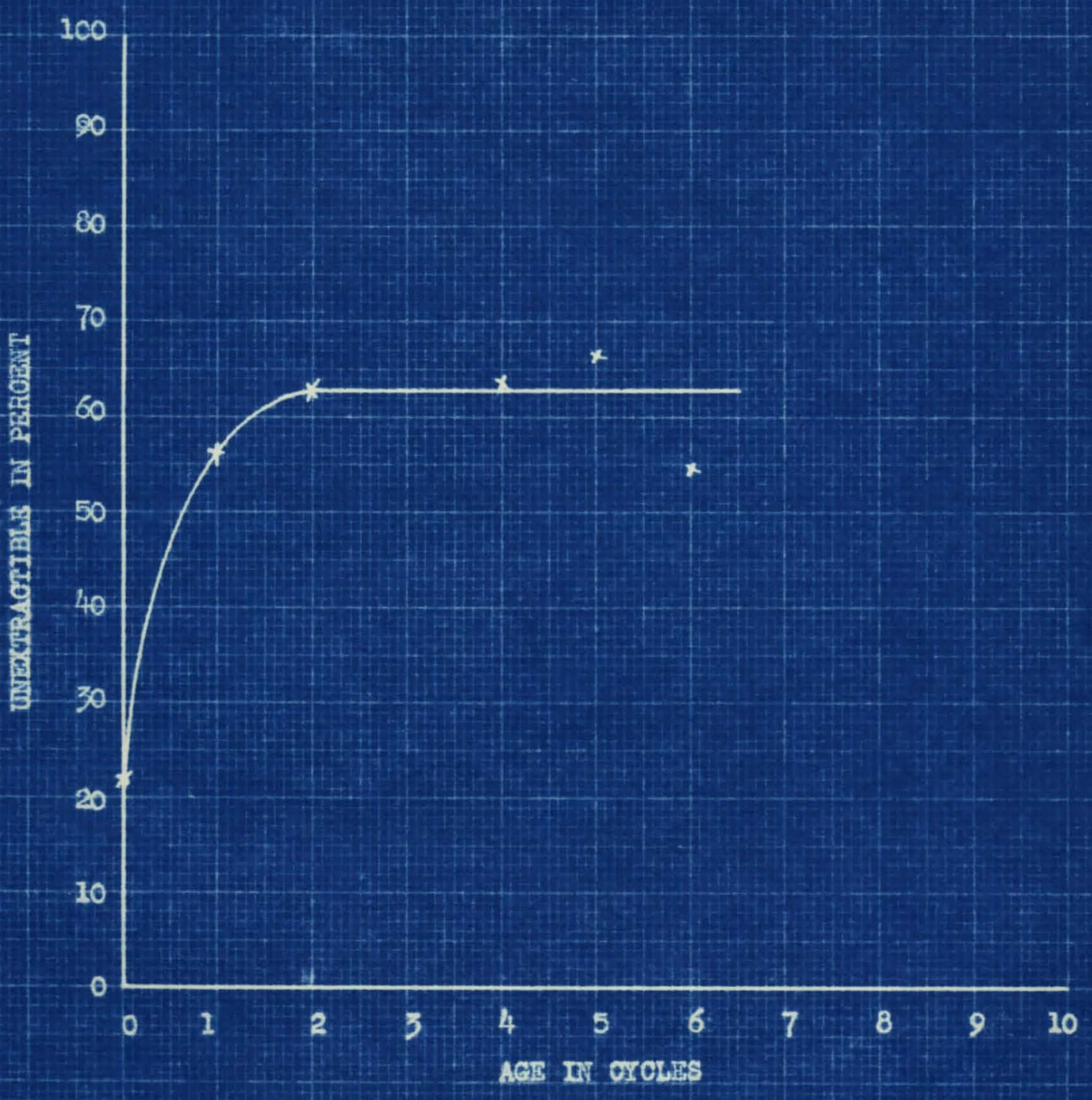

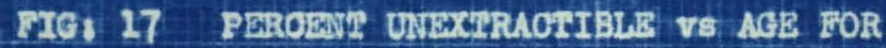
GonveO RESTH BIIM 


\section{TABLE VIII}

\section{Percent Unextractible of Filmo at Failure}

Varnish \% 011 \% Resin \% Unextractiblo

33 Lin. $72.5 \quad 27.5 \quad 73.0$

25 Lin. $66.6 \quad 33.3 \quad 80.0$

16 Lin. $56.2 \quad 43.8 \quad 72.0$

8 Lin. $\quad 39.0 \quad 61.0 \quad 36.0$

33 Tung $72.5 \quad 27.5 \quad 75.0$

25 Tung $66.6 \quad 33.3 \quad 77.0$

16 Tung $56.2 \quad 43.8 \quad 68.0$

8 Tung $39.0 \quad 61.0 \quad 52.0$
Enamel \% 0il \% Resin \% Unextractible

$\begin{array}{rrrr}33 \text { Lin. } 82.5 & 17.5 & 74.0 \\ 25 \text { Lin. } 78.7 & 21.3 & 83.0 \\ 16 \text { Lin. } 72.0 & 28.0 & 80.0 \\ 8 \text { Lin. } 61.0 & 39.0 & 63.0 \\ 33 \text { Tung } 82.5 & 17.5 & 82.0 \\ 25 \text { Tung } 78.7 & 21.3 & 80.0 \\ 16 \text { Tung } 72.0 & 28.0 & 71.0 \\ 8 \text { Tung } 61.0 & 39.0 & 69.0\end{array}$

25 Lin. $78.7 \quad 21.3 \quad 83.0$

16 Lin. $72.0 \quad 28.0 \quad 80.0$

8 Lin. $61.0 \quad 39.0 \quad 63.0$

$\begin{array}{lll}33 & \text { Tung } 82.5 \quad 17.5 \quad 82.0\end{array}$

25 Tung $78.7 \quad 21.3 \quad 80.0$

8 Tung $61.0 \quad 39.0 \quad 69.0$ 
DISOUSSION OF RESULTS 
The curves representing polymerization rates for the varnishes and onemelo (curves A \& B in Figs. 7-16) tend to rise with a relatively eteep slope during the early life of the film and gradually taper off eoympotically as aging continues. The failure points on these curves occur nearer the abympotic values as the oil lengthe Increase. This is shown directly on the varnieh and enamel curves of Figs. 7-10 and 12-15 and indirectly by curves $A$ and B of Fige. 11 and 16 where no failure occurred in 10 cycles for infinite ofl length samples (stralght oil) and on curve A of Fig. 17, where fallure of the straight resin sample occurred before the first cyole was completed.

The extraction data was obtained under such conditions that an error of $\pm \%$ does not seem unreasonable from the experimental point of view. The varnish and enamel curres $A$ and $B$ (Figs. 7-9, 12-14) of the 33, 25, and 16 gallon lengthe for both oils have two things in common that appear conclusive. Each enamel curve tapers slower but to approximately the same asympototic value as Its corresponding varnish curve. Thus the change in rate of polymerization is slower in the enamels than in the varnishes. Also, the failure point on each enamel curve occurs within two or less cycles 108 s time than for the corresponding varnish but at the same unextractible value. It appears that not only does failure occur in a film when polymerization has gradually reached a definite point but the pigment incorporated in a varnish to form the enamel is 
definitely counted as 'polymer' and because of its presence will probably decrease the durability of the film as a protective coating. This oupports the theory presented in that the pigment bound In the structural network is sharing in the complexity of the Pilm and reducing the number of chance contacts that the functional groups have with one another. This also explains why the rate of polymerization was slower in the enamele than in the case of the varnishes. Apparently the percent of 'polymer' contained in the various formulations when failure occurred vary with the oil selected and with the ratio in which it is used with the resin. See Table VIII for these values. It is important to bear in mind that the pigment was added to the varnishes on a solida basis thus ahortening the actual oil length of the enamel samples. Had the enamels been adjuated back to the proper oil lengths the age differences in failure occurrences would probably have been diminished to near zero. If the error in the distensibility tests is considered $\pm 2 \%$ and the elongation curves are corrected by this value (curves $C$ and D, Figs. 7-16) so as to move the left coordinate to the right $2 \%$ (or less) it can be seen (where elongation curves were obtained) that the new zero elongation value occurs within the allowable range of the previously determined polymer value at which failure occurred. For example, shift the left vertical coordinate of P1g. 7 to the right 2 units $(2 \%)$, curves $O$ and $D$ cross this axis at $72 \%$ and $78 \%$ respectively and are approximately within $\pm 3 \%$ of the $75 \%$ polymer 
value which was previously located by inspection. This shows a fair correlation between the two methode employed to determine Pilm failure.

Correlation is difficult for the tenoilo strength data because of its fluctuatione. This can be accounted for by the inacouracy of the film thicknesses and their measurement. Schuh and Theurer (17) have stated several variables that determine dietensibility which aid in explatning what may have caused the discrepencies in this data. They are: (a) corposition of the film-forming material, (b) thickness of the film, (c) age and history of the film, (d) temperatare and humidity at time of tost, (e) and the rate of strees application.

A set of composite curves wes developed to determine what relation exista between the resin, 011 and pigment on polymerization. Each ourve (MgB, 18-25) is based on the polymerization curves of the individual materials in their proper ratios as used in formulating the varnishes and enamels. Actually thoy are the reoults of adding the curves of the individual terials which have been multiplied by the proper ratio. For example, a so-celled composite polymerization curve for a 33 gallon lineeed varnish would be an additive curve obtained by multiplying the polymerization data (percont unextractible data at various ages) for the reain by the ratio in which the resin occurs in the solid content of an actual 33 gallon varnioh and adding to this data, at the proper aging 
periods, the polymerization data for the gtraight linseed oil which has been multipliod by its occurring ratio. Ourve A of Pig. 18 was obtained by multiplying curve $A$ of Fig. 7 by $72.5 \%$ (the ratio of oil in the solid content of a 33 gallon varnish, seo Table VIII) and adding to it curve $A$ of Fig. 17 which has been maltiplied by 27.5\%. In other words, the actual curves of the individual materials were diminished by that fraction in which the terials appear in the combined formulatione afterwhich the resulting curves were added together. Each composite ensmel curve is composed of a pigmented oil curve and a resin curve obteined in a similar manner.

By comparing the composite curves wh their correaponding varnith and enamel curres (compare Figs. 18-25 with Figs. 7-10 and Pigs. 12-15) it is observed that they are in general analogous, having similar curvature and comparable asymptotic ralues. This leads to the conclusion that the polymerization occurring in the combined formulations is no different from that occurring in the individual materials. This suggeste that the degree of polymerization of a film forming material at a given age can be predetermined use of previously determined information on the basic materials used. Where the point of failure falls on the composite curve thas produced can not be determined by this procedure developed thus far.

The pigment used in this investigation was inert. Whother a reactive pigment would behave differently is not within the sope of this investigation. 


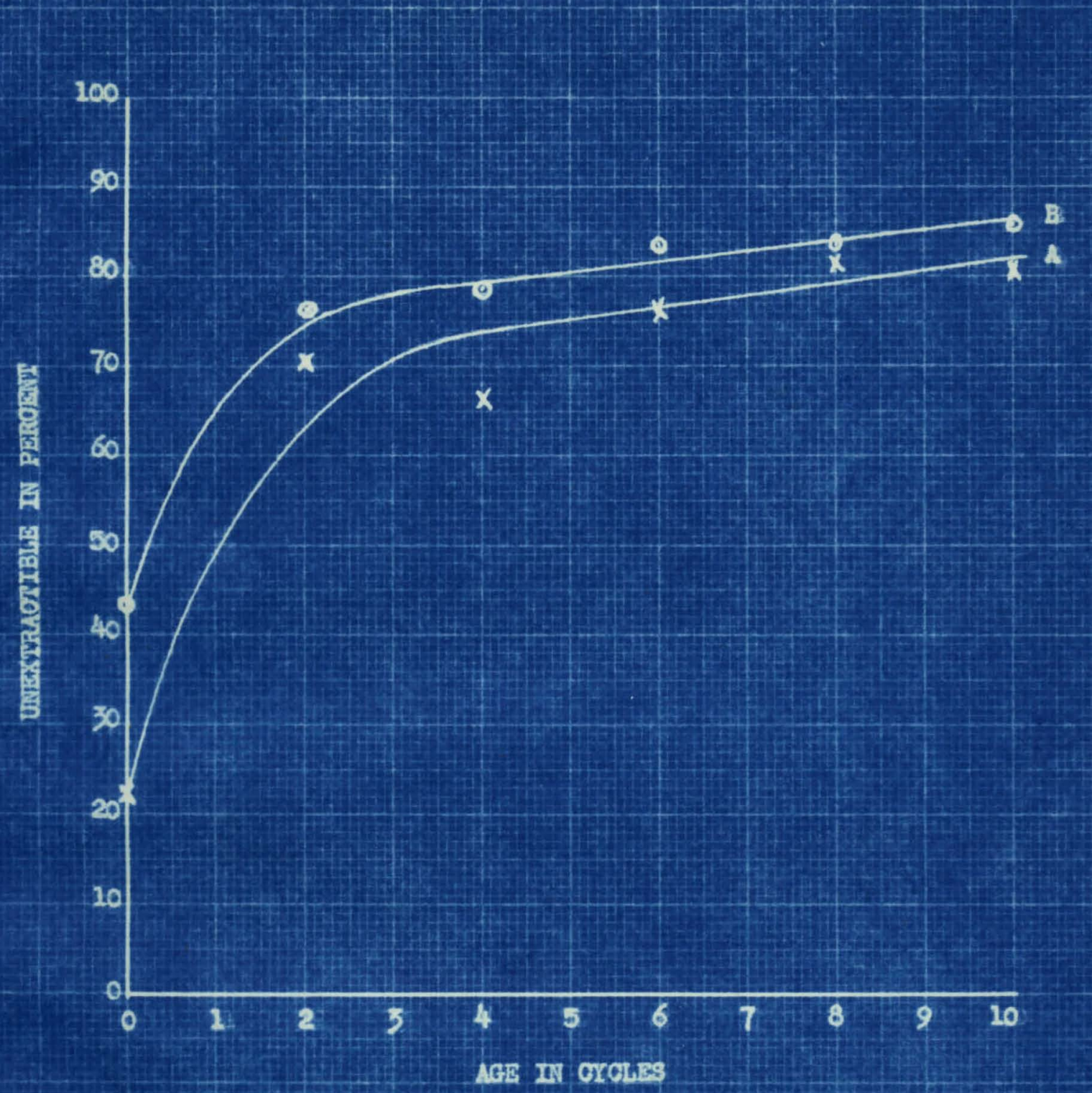

A. $33 \mathrm{gal}$. varnish

B $33 \mathrm{gal}$. chanel

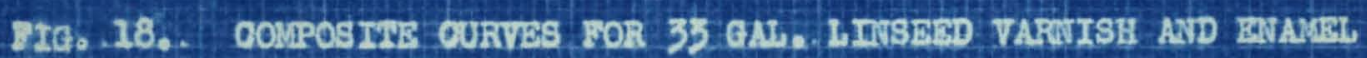




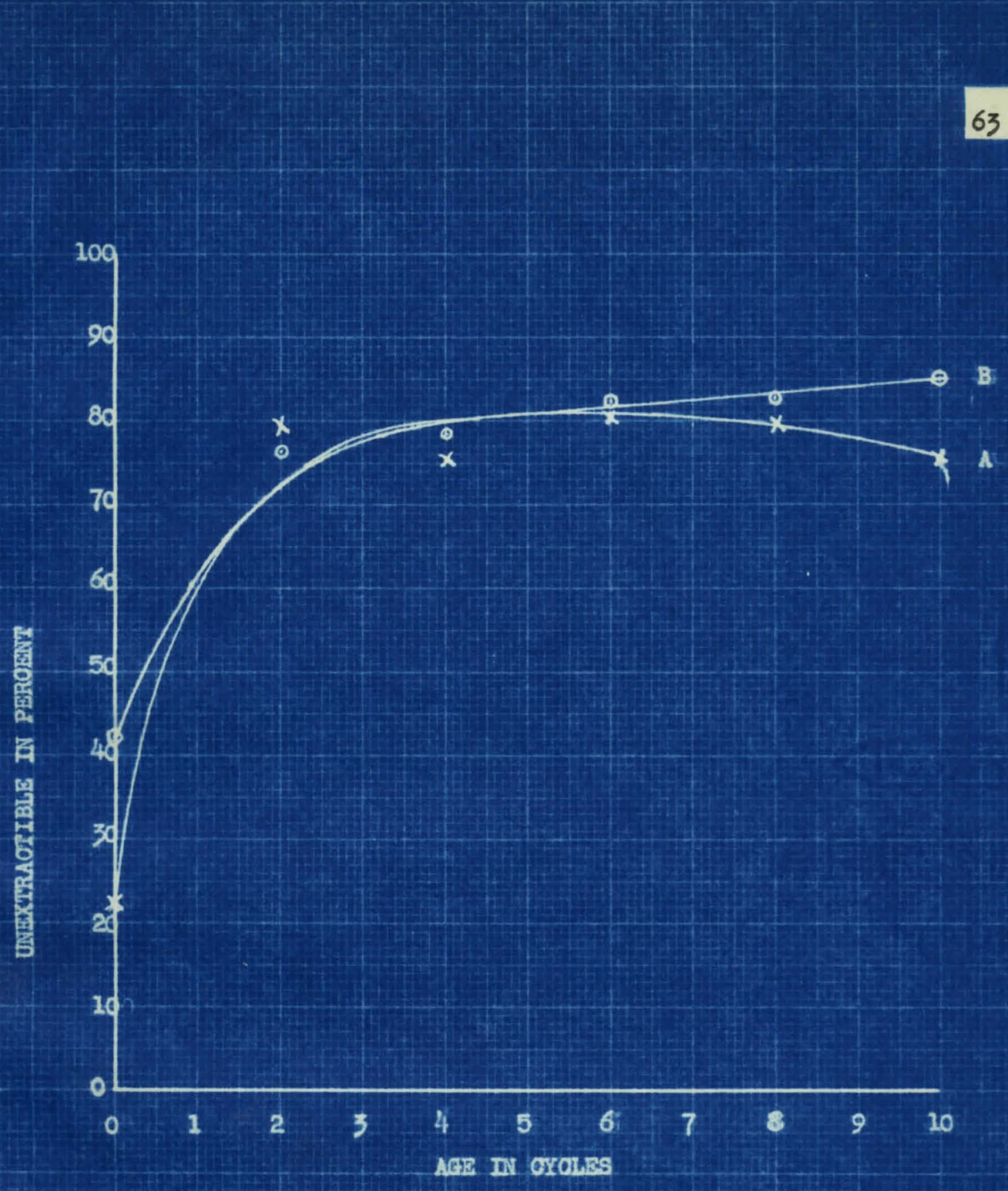

A $25 \mathrm{gal} . \mathrm{rarnb}$

B. $25 \mathrm{gal}$. Bnamel

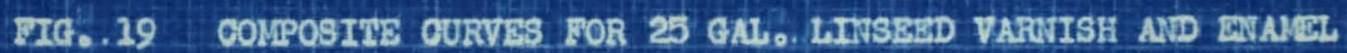




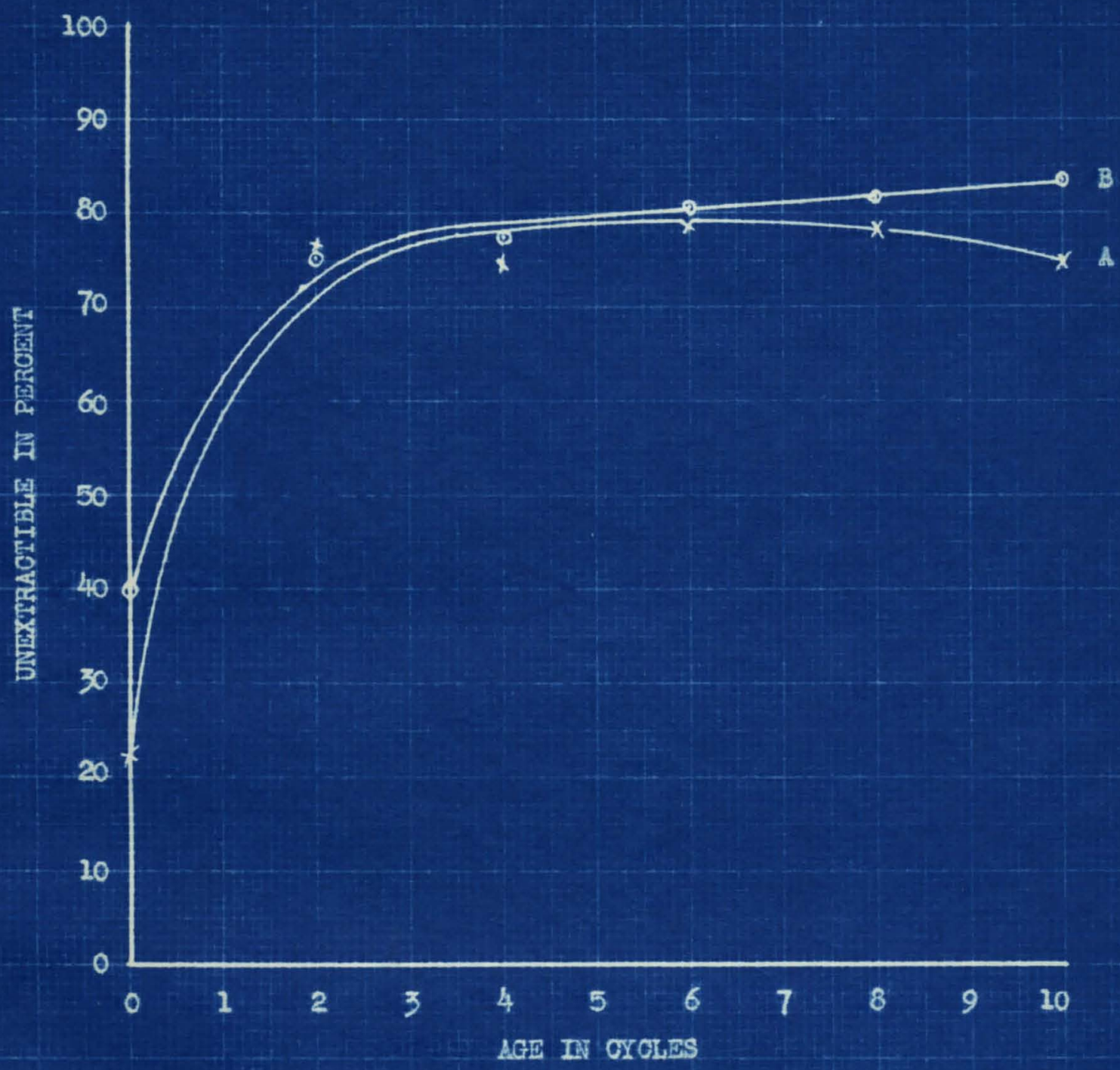
A 16 gal. ramioh
B 16 gal. enanel

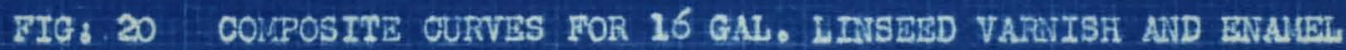




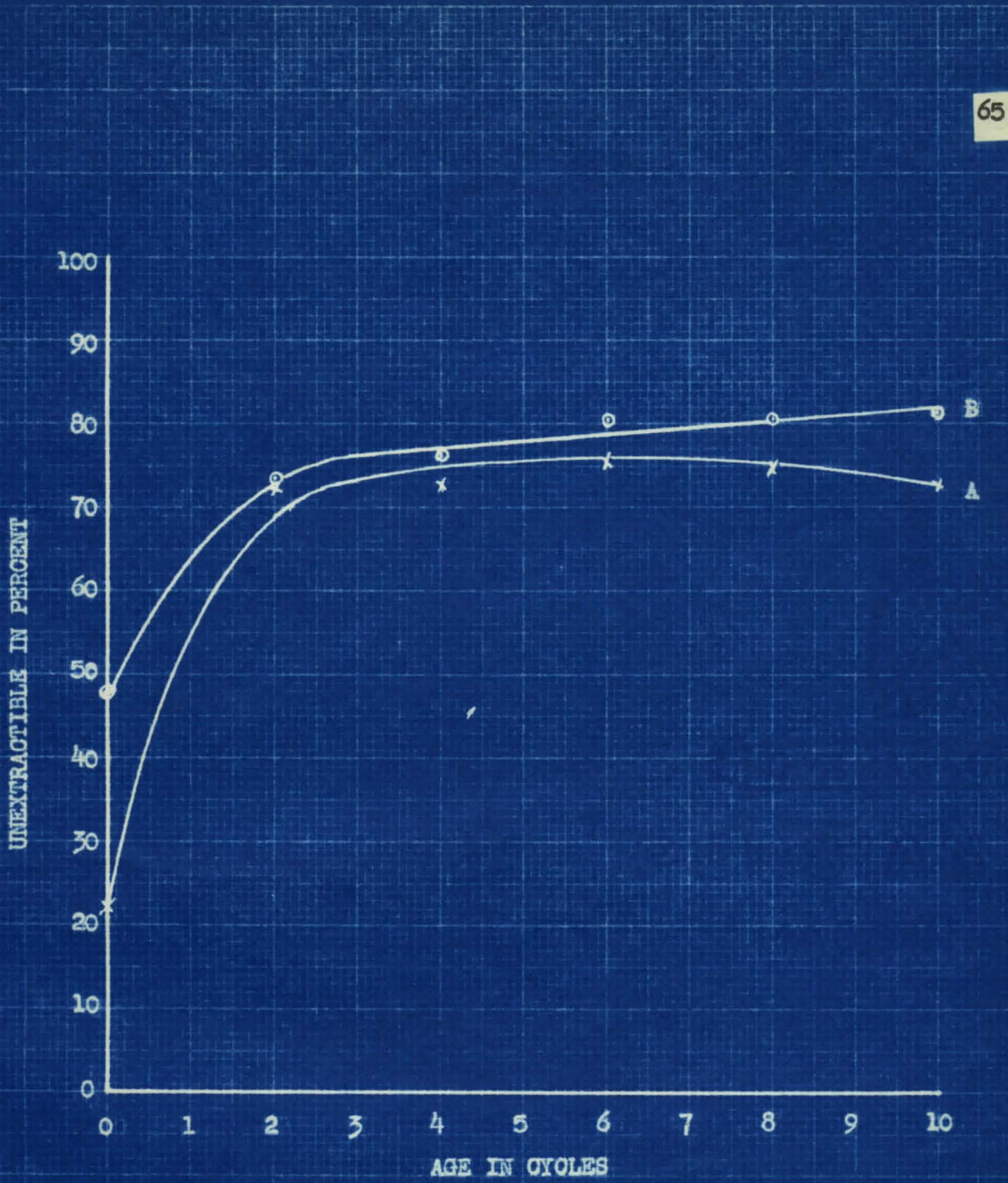

A 8 gal. varnioh

B 8 gal. anamel

FIG. 21 COMPOSINE CURVBS TOR 8 GAL,. LINSEBD VARUISH AND ERTAREL 


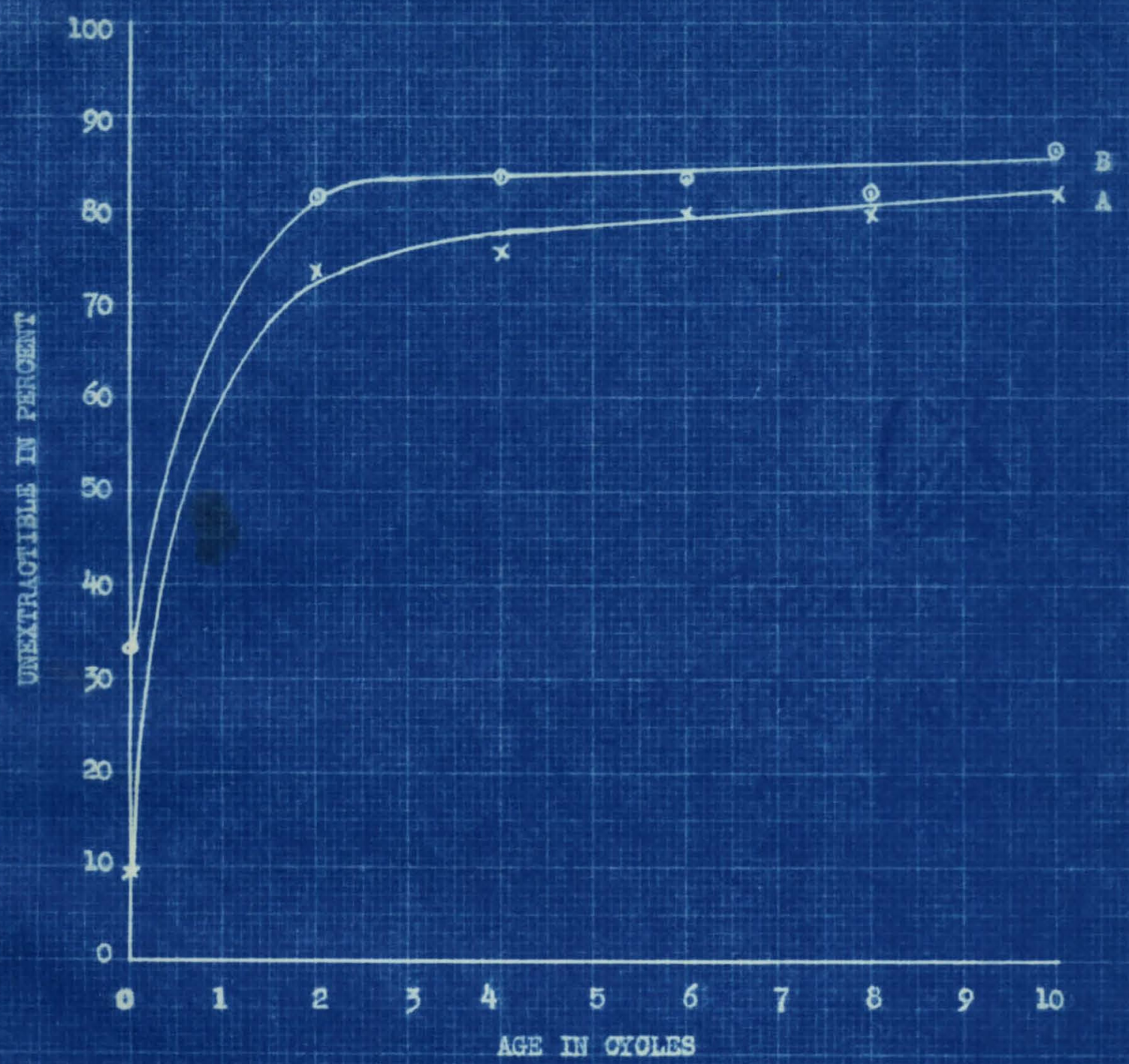
A 33 gal. varnish
B. 33 gal. enamol

RIC. 22 COMPOSITE CURVES FOR 33 GAL. TUIG VARUISH AMD BINGE 


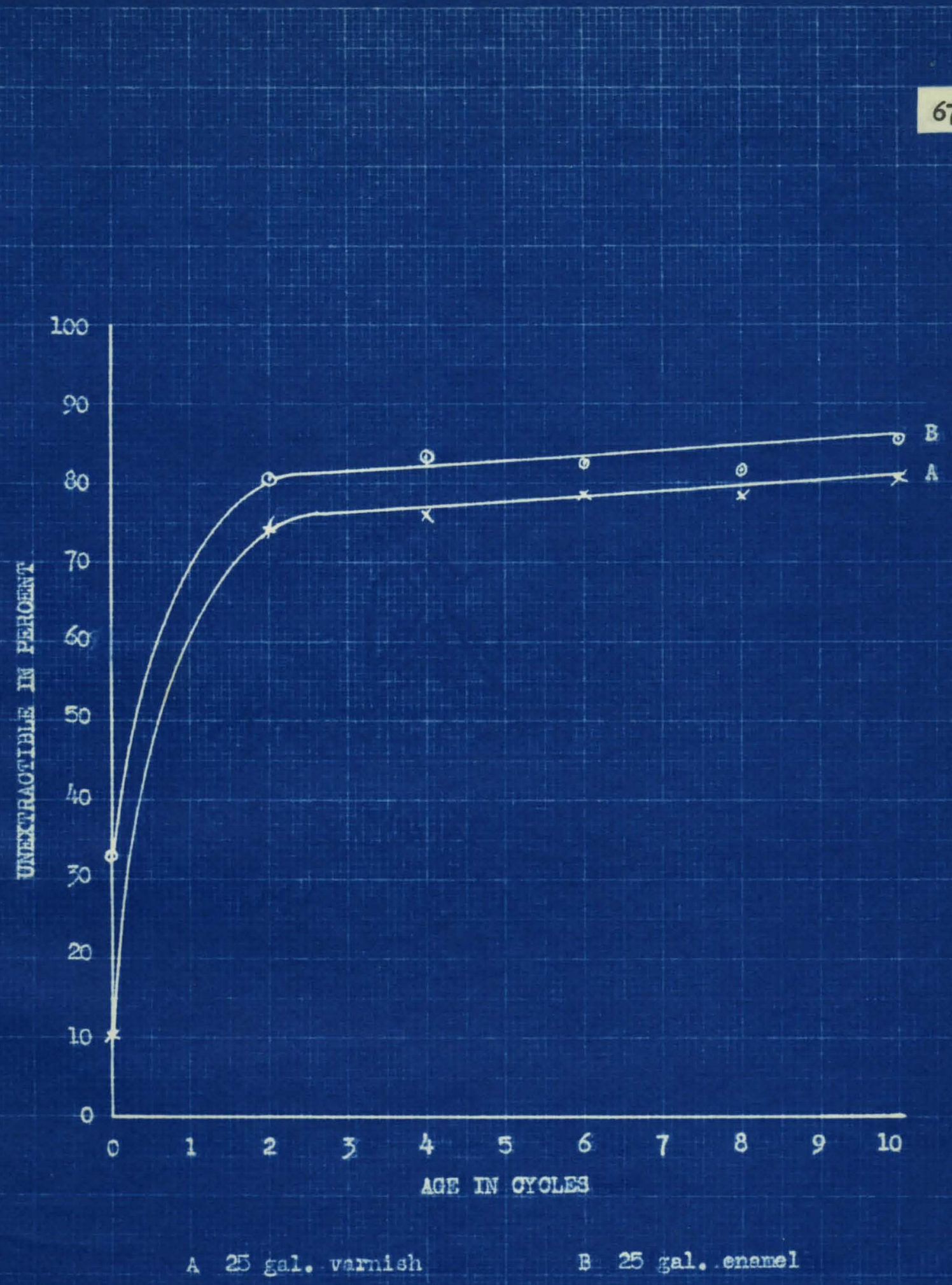

FIG. 23 COMPOSITE CURVES FOR 25 GAL. TUIG VARIISH AND BHAMEL 


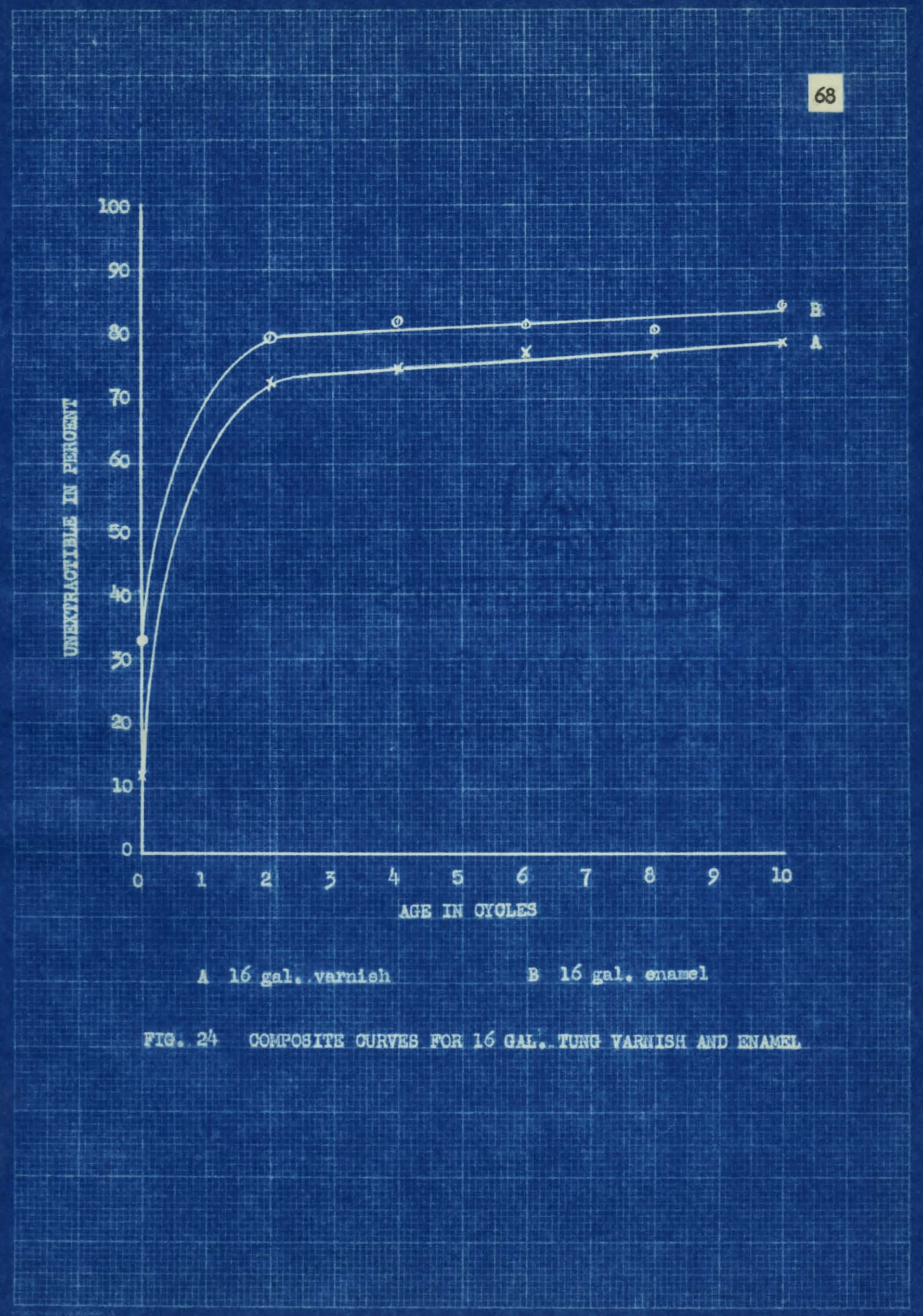




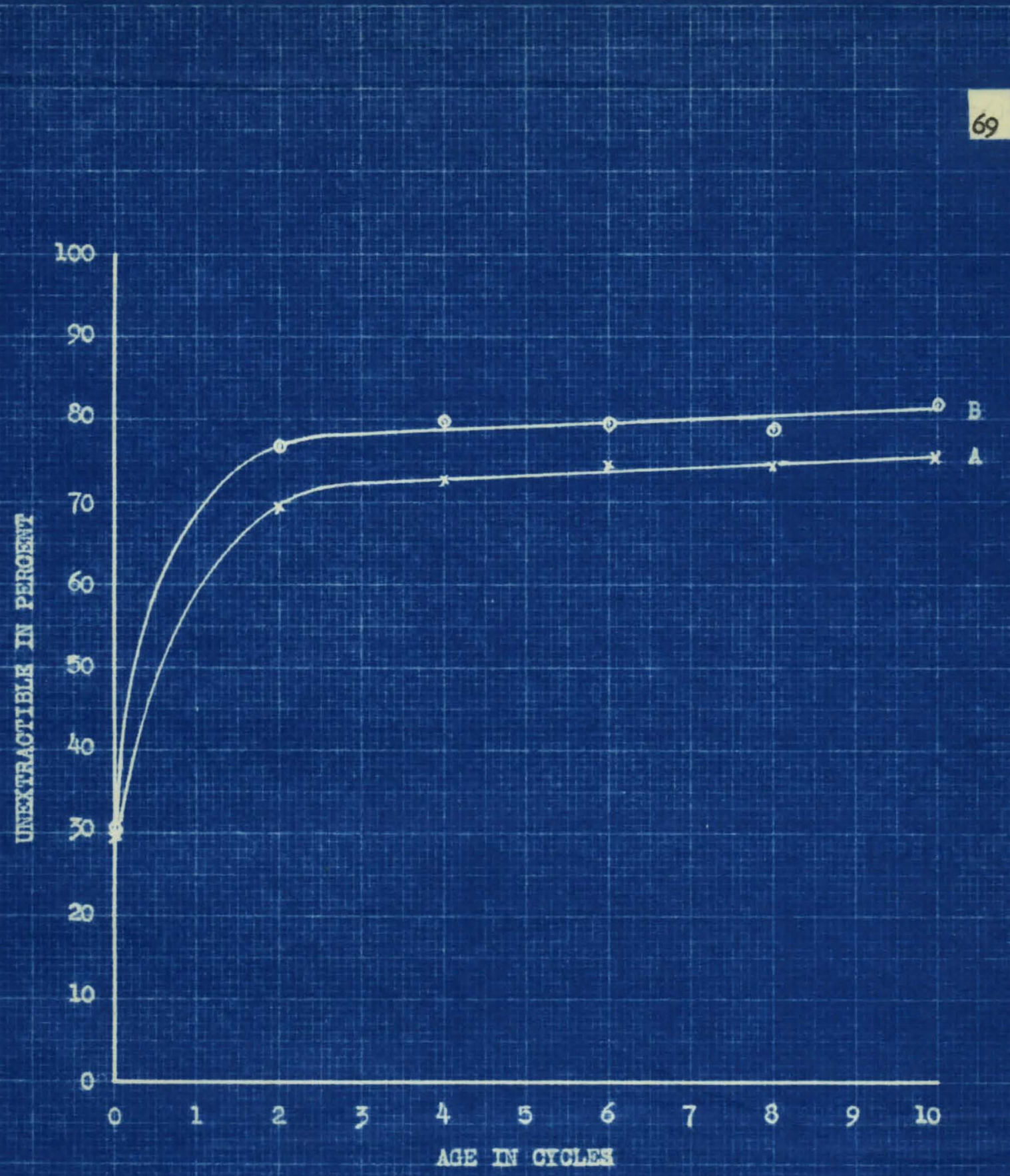
A 8 gal, yamileh
B 8 gal. onanol

FIG. 25 GOKROSITE GURVES FOR 8 GN. TUNG VAFNISH AND ENAMAL 
CONCLUSIONS 
Results of the Invertigation of studying the effect of aging on the distensibility and unextractible properties of oleoresinous film structures lead to the following conclusions:

(1) By extracting films of the basic materials, the procedure dereloped can be used to predetermine the rate of polymerization curves for oleoresinous films provided any pigmonts used are inert and the oil length of the varnieh or enamel is oufficiently long to withstand several acceleratod aging periods.

(2) Film fallure occurs when the degree of polymerization has reached approximately $70-80 \%$, however, the procedure as dereloped is incapable of predicting the expected durability of oleoresinous films.

(3) Oleoresinous film structure is apparently of such a nature that the molecules orfent themselves during the aging process to impart elasticity to the film during the early stages of polymerization and brittleness during the last stages. Thus film failure occurs when the polymerization has proceded to such an extent that the film has lost its elastic properties.

(4) An enamel and a varnish composed of the same materials and constituting approximately the same oil length fail at the same degree of polymerization, however, the enamel polymerizes more elowly.

(5) Inert pigment in onamels must be counted as 'polymer' in an enamel film. 
L I TERATURE CITED 
(1) Blom, A.V., Kolloid-2., 75, 223, (1936).

(2) Bradley, T.F., Ind. Eng. Chem, 29, 440-5, (1937).

(3) ibid, $30,689,(1938)$.

(4) Bradley, T.P., and Pfann, H.F., Ibid, 32, 694, (1940).

(5) Burk, Thompson, Woith, Williams, 'Polymerization and Its Applications in the Flelds of Rubber, Synthetic Resins, and Petroloum', 210-211, Reinhold Publiahing Corporation, Now York, (1937).

(6) Carothers, W.H., and Arvin, J.A., J. Am. Chem. Soc., 51, 2560, (1929).

(7) Cutter, J.O., and Jordon, L.A., J. 011 Colour Chem, Assoc., 18,5 , (1935).

(8) Diels, O., and Alder, K., Ann., 460, 98, (1928).

(9) Elm, A.0., Ind. Eng. Ohem., 23, 881, (1931).

(10) Gardner, H.A., 'Physical and Chemical Examination of Paints, Varnishes, Lacquers, and Colours', pages 94 and 99, Institute of Paint and Varnish Research, Washington, D.O., (1939).

(11) Kienle, R.H., Ind. Eng. Chom., 25, 971, (1933).

(12) Tbid, Paint Toch., 1, 189, (1936).

(13) Long, J.s., and Mccarter, W.S.M., Ind. Eng. Chem., 23, 786, (1931).

(14) Long, J.S., Reineck, A.E., and Ball, G.L., Ibid, 25, 1086, (1933).

(15) Overholt, J.L., and Elm, A.C., ibid, 32, 378, (1940).

(16) Rose, C.H., and Bolley, D.S., 1bid, 28, 115, (1936).

(17) Schuh, A.E., and Theurer, H.C., Ind. Eng. Ohem. Anal. Ed., 9, 9, (1937).

(18) 1bid, Ind. Eng. Chem., 29, 182, (1937). 
A P P N D I X 


\section{ACKNOWLEDGEMERTS}

The author wishes to thank the Federation of Paint and Varnioh Production Clube for the grant that made this investigation poseible.

He also wants to express his appreciation to $M r$. Otto J. Milet1, Dr. J.S. Long, and Mr. H.L. Beakes, members of the Loulsville Production Club, who served as a local comittee on research for the Federation and supervised this problem, and to Mr. William H. Lubbers who ably assisted in the routine work, to Mr. Benjamin Rabin who assisted in cooking the rarnieher, to Mr. A.L. Munsen and Mr. Lucky who assisted in the accelerated weathering and to Dr. H.S. Brom and Mr. Alfred Graaf for pigmenting suggestions, and to the following companies for their donations of materials:

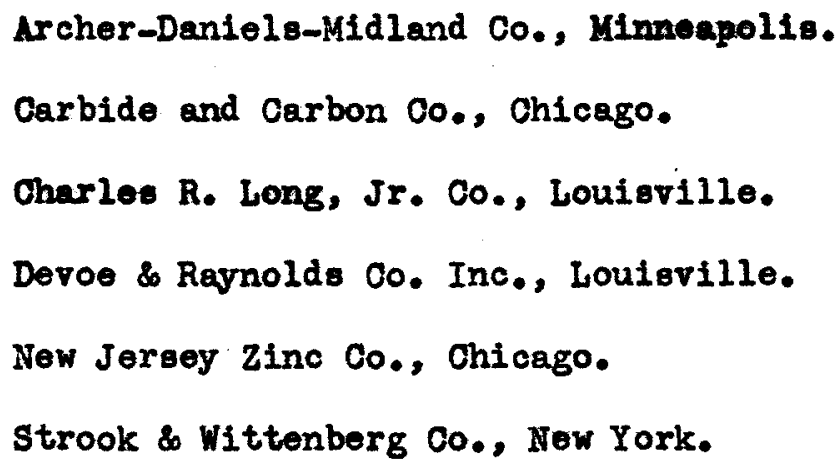


VITA

Frank Rush McQuitkin was born in Roanoke, Virginia on May 3, 1917, the son of Dwight Eggelston McQuilkin and Ethel Belle Jones. He recelved his primary and high school education in the public schools of Roanoke. He studied freshman engineering courses at Roanoke College, 6alem, Virginia, received Bachelor of science in Chemical Engineering Degree from the Virginia Polytechnic Institute, Blacksburg, Virginta, in June 1939, and recelved a Master of Chemtcal Engineering Degree from the University of Louibville, Louisville, Kentuck, in Auguet 1940.

He was awarded the Federation of Paint and Varnieh Production Olube Fellowship at the University of Louisville for the year 1939-1940, and upon completion of his academic work was employed by the Southern Varnish Corporation in Roanoke, Virginia. Mr. MeQuilkin 18 a mober of Tau Beta P1, national honorary ongineoring fraternity, Phi Lambda Upsilon, national honorary chemiatry fraternity, and Phi Kappa Phi, national ocholastic fraternity. He was president of the V.P.I. student chapter of the Amorican Institute of Chemical Engineers, vice-president of the Alpha Theta chapter of Phi Lambda Upsilon, and a member of the V.P.I. Engineers' Counc1l. 